\title{
Porphyry-Related Metamorphosed Au-Ag and Cu-Mo Deposits in the Precambrian of the Fennoscandian Shield
}

\author{
Arkadii A. Kalinin * (D) and Nikolay M. Kudryashov \\ Geological Institute, Kola Science Center, Russian Academy of Science, Apatity 184200, Russia; \\ nik@geoksc.apatity.ru \\ * Correspondence: kalinin@geoksc.apatity.ru; Tel.: +7-921-663-68-36
}

check for updates

Citation: Kalinin, A.A.; Kudryashov, N.M. Porphyry-Related

Metamorphosed Au-Ag and Cu-Mo Deposits in the Precambrian of the Fennoscandian Shield. Minerals 2021, 11, 139. https://doi.org/10.3390/ $\min 11020139$

Academic Editor: Galina Palyanova Received: 18 January 2021

Accepted: 25 January 2021

Published: 29 January 2021

Publisher's Note: MDPI stays neutral with regard to jurisdictional claims in published maps and institutional affiliations.

Copyright: (c) 2021 by the authors. Licensee MDPI, Basel, Switzerland. This article is an open access article distributed under the terms and conditions of the Creative Commons Attribution (CC BY) license (https:// creativecommons.org/licenses/by/ $4.0 /)$.

\begin{abstract}
The Pellapahk Cu-Mo and Oleninskoe Au-Ag deposits in the western segment of the Russian Arctic in the Kolmozero-Voronya greenstone belt are considered two parts of an Archean (2.83-2.82 Ga) porphyry-epithermal system, probably the oldest one defined in the Fennoscandian Shield. Formation of the Oleninskoe Au-Ag deposit at the epithermal stage of the system is indicated by the spatial and genetic relationships with the sills of granite porphyry, the geochemical association of ore elements $(\mathrm{Au}, \mathrm{Ag}, \mathrm{Cu}, \mathrm{Pb}, \mathrm{Sb}, \mathrm{As})$, an $\mathrm{Au} / \mathrm{Ag}$ ratio of $<0.2$, and the multiplicity of silver mineralization with different $\mathrm{Ag}, \mathrm{Cu}, \mathrm{Pb}, \mathrm{Sb}$ sulfosalts. The geological-structural characteristics of the Oleninskoe and the Pellapahk, i.e., their location in a shear zone, the morphology and size of ore bodies, the scale of the deposits, and the intensity and zoning of rock alteration, do not oppose this model. Mineralized rocks of the Pellapahk $\mathrm{Cu}-\mathrm{Mo}$ and Oleninskoe Au-Ag deposits were amphibolite metamorphosed in the Neoarchean and again in the Paleoproterozoic. Structures of sulfide melt crystallization formed in the ores during metamorphism, those are fine intergrowths of galena, argentotetrahedrite, pyrargyrite, pyrrhotite, ullmannite, stutzite, and other mineral phases of low-melting-point metals such as $\mathrm{Ag}, \mathrm{Cu}, \mathrm{Pb}, \mathrm{Sb}, \mathrm{As}, \mathrm{Bi}$.
\end{abstract}

Keywords: Fennoscandian Shield; Kolmozero-Voronya belt; Oleninskoe Au-Ag deposit; Pellapahk porphyry deposit; alteration, gold; silver

\section{Introduction}

Porphyry deposits are the major sources of $\mathrm{Cu}, \mathrm{Mo}$, and Re in the world [1]; they also provide significant amounts of $\mathrm{Ag}, \mathrm{Au}$, and some other metals. These deposits are the products of large hydrothermal systems that developed due to magmatic-hydrothermal phenomena in and around intermediate-to-felsic intrusions, emplaced at relatively high levels in the crust (1-6 km below the paleosurface) [1,2]. Metal-rich fluids exsolve from the shallow-crustal intrusive complexes and alter and mineralize the upper parts of the causative intrusions and the surrounding country rocks. These may be simple systems, consisting of a single intrusion with an associated alteration halo and a high-temperature ore, or more complicated systems of numerous intrusions with overlapping stages of alteration and ore deposition that formed over a wide range of temperatures [3].

Rock crystallization occurs due to pressure quenching, generating the diagnostic porphyritic texture of the mineralizing intrusions. Episodic brittle failure and fluid release from the crystallizing magmas produce a multistage vein stockwork that hosts the bulk of the ore [4]. Mineralization styles include stockwork veins, hydrothermal breccias, disseminations in the groundmass and, rarely, wall-rock replacements.

Epithermal fluids can potentially dissolve significant amounts of gold and silver from porphyry deposits, because the solubility of precious metals, such as aqueous bisulfide complexes, increases with decreasing temperatures when aqueous $\mathrm{H}_{2} \mathrm{~S}$ contents remain high [5]. Late-stage processes commence the final stage of porphyry ore formation and the formation of peripheral Ag-Au ore deposits. 
Porphyry Cu-Au-Mo deposits mostly formed in the tectonic setting of continental and oceanic arcs, concentrated in the Pacific Rim. They also occur in the Tethyan arc from Europe to Asia, and others are scattered in volcanic arcs of all ages, with rare examples as old as the Archean [6-8]. The rarity of porphyry deposits in the Precambrian provokes a particular interest in their investigation.

The Archean Cu-Mo porphyry deposit of Pellapahk in the Kolmozero-Voronya greenstone belt (Kola Peninsula) is the only porphyry deposit in the northeastern part of the Fennoscandian Shield [9]. Cu-Mo mineralization was discovered in 1975 and studied in the 1970s and 1980s by the Central Kola Expedition (Monchegorsk, Russian Federation), and later in 2003-2010 by JSC Black Fox Resources (Ovoca Gold group) with diamond drilling (total 68 drillholes) and minor trenching. As a result of the investigations, a large stockwork of a complicated form with poor ores (200.5 million tons of ore with an average Mo content of $0.028 \%, \mathrm{Cu} 0.154 \%, 2.0 \mathrm{~g} / \mathrm{t} \mathrm{Ag}$, and $0.08 \mathrm{~g} / \mathrm{t} \mathrm{Au}$ ) [10,11] was contoured and traced down to a depth of $360 \mathrm{~m}$. Cu-Mo mineralization was shown to be economically valuable in the case of an increase in the price of molybdenum [9].

The Oleninskoe gold-silver deposit and numerous gold occurrences are located in a neighborhood of the Pellapahk. Gold mineralization in the Oleninskoe deposit was discovered in 1969-1972 [12], and studied in the 1970s and 1980s by the Central Kola Expedition (Monchegorsk, Russian Federation), in 1997-1998 by Voronya Minerals JSC (Boliden AB group), and later in 2005-2008 by Black Fox Resources JSC (Ovoca Gold group) with intense trenching and drilling (total 61 drillholes). The Oleninskoe is a medium gold deposit, consisting of a number of mineralized lenses, with average gold content of $7.6 \mathrm{~g} / \mathrm{t}$. Resources of $\mathrm{Au}$ in the deposit are estimated at $10 \mathrm{t}$ [13], while Ag resources have not been estimated. The Oleninskoe differs from all other gold deposits in the northeastern part of the Fennoscandian Shield in diverse mineralization of $\mathrm{Pb}, \mathrm{Ag}$, $\mathrm{Sb}$, and $\mathrm{Au}$. We consider the Oleninskoe deposit as a part of an Archean porphyry-epithermal system. This new genetic model of the mineral deposits in the Kolmozero-Voronya belt is discussed below.

\section{Materials and Methods}

Gold, silver, and Cu-Mo mineralization was studied in the specimens and samples $(1.5-10 \mathrm{~kg})$, collected by the authors in the outcrops and trenches in 1981-1983, then in 1997-1998, and again in 2017. Investigations of wall-rock alteration, metasomatic zoning, and determination of pre-ore, ore-related, and post-ore mineral assemblages in altered rocks were based on the study of rocks in the outcrops and in drillcores, the examination of mineral relations in thin and polished sections, as well as on the results of assays of primary and altered rocks. The samples were assayed for major (rock-forming) elements, Au and $\mathrm{Ag}$, in the chemical laboratory of the Geological Institute, Kola Science Centre of Russian Academy of Sciences, Apatity, Russia with flame atomic absorption spectrometry (FAAS), and with pre-concentration of gold and silver with p-alkylaniline and oil sulfides. The data on trace elements, which determined the geochemical characteristics of the deposits, were obtained by ICP-MS in the Institute of Geology and Geochemistry of the Ural Branch of the Russian Academy of Science, Ekaterinburg, and in the Institute of Geology of Ore Deposits, Mineralogy, Geochemistry, and Petrography (IGEM), Russian Academy of Science, Moscow.

Mineral composition of the ores was studied in thin and polished sections with the reflected light microscope Axioplan 2 Imaging (Karl Zeiss, Jena, Germany), and with the electron microscope LEO-1450 (Karl Zeiss, Jena, Germany) in the Geological Institute of the Kola Science Center.

The preliminary estimation of the composition of mineral species was performed with the energy-dispersive system Bruker XFlash-5010. Microprobe analysis (MS-46, CAMECA, Gennevilliers Cedex, France, 22 kV; 30-40 nA, standards (analytical lines): $\mathrm{Fe}_{10} \mathrm{~S}_{11}(\mathrm{FeK} \alpha$, $\mathrm{SK} \alpha), \mathrm{Bi}_{2} \mathrm{Se}_{3}(\mathrm{BiM} \alpha, \operatorname{SeK} \alpha), \mathrm{LiNd}\left(\mathrm{MoO}_{4}\right)_{2}(\mathrm{MoL} \alpha), \operatorname{Co}(\mathrm{CoK} \alpha), \mathrm{Ni}(\mathrm{NiK} \alpha), \operatorname{Pd}(\operatorname{PdL} \alpha)$, $\operatorname{Ag}(\operatorname{AgL} \alpha), \operatorname{Te}(\operatorname{TeL} \alpha), \operatorname{Au}(\operatorname{AuL} \alpha)$ was performed for grains larger than $20 \mu \mathrm{m}$ (analyst Ye. Savchenko). The identification of some rare mineral phases was verified with X-ray 
analysis in the Geological Institute of the Kola Science Center (analyst E. Selivanova). Visually homogenous material of $50 \times 10 \mu \mathrm{m}$ or more in size was extracted from the polished sections and examined with the $\mathrm{X}$-ray powder diffraction (Debye-Scherer) on URS-1 (Burevestnik, Irkutsk, Russia) operated at $40 \mathrm{kV}$ and $16 \mathrm{~mA}$ with an RKU-114.7 mm camera and $\mathrm{FeK} \alpha$ radiation.

The assaying of fluid inclusions was performed by Vsevolod Prokofiev (IGEM) in $0.5 \mathrm{~g}$ quartz samples, collected from $-0.5+0.25 \mathrm{~mm}$ fraction with methods described in [14] (analyst Yu.Vasyuta, TsNIGRI, Moscow, Russia). The inclusions in quartz were thermally disclosed at $500{ }^{\circ} \mathrm{C}$. The quantity of water for the calculation of element concentration in the solution, carbonic acid, methane, and other hydrocarbons was defined with the method of gas chromatography on a TsVET-100 chromatograph (Dzerzhinsk, Russia). $\mathrm{Cl}, \mathrm{SO}_{4}$, and F were assayed with ion chromatography on a TsVET-3006 (detection limit $0.01 \mathrm{mg} / \mathrm{L}$ ), and $\mathrm{K}, \mathrm{Na}, \mathrm{Ca}$, and $\mathrm{Mg}$ with ICP-MS in aqueous extracts.

Zircon U-Pb dating was undertaken at the Geological Institute of the Kola Science Center. Prior to analysis, zircons were extracted using standard magnetic and heavy liquid separation, with surface contamination removed using alcohol, acetone, and $1 \mathrm{M} \mathrm{HNO}_{3}$.

The zircon dissolution and chemical recovery of $\mathrm{Pb}$ and $\mathrm{U}$ was performed using the technique described in [15], with $\mathrm{U}$ and $\mathrm{Pb}$ concentrations determined by isotope dilution employing a Finnigan MAT-262 (RPQ) (Finnigan MAT, San Jose, CA, USA) mass spectrometer and a mixed $208 \mathrm{~Pb}+235 \mathrm{U}$ tracer, with silica gel used as an ion emitter. Blank levels had maximum values of $100 \mathrm{ng} \mathrm{Pb}$ and $10-50 \mathrm{ng} \mathrm{U}$, and all isotope ratios were corrected for mass fractionation by analysis of the SRM-981 and SRM-982 standards $(0.12 \pm 0.44 \%)$. The uncertainties of the resulting $\mathrm{U}-\mathrm{Pb}$ ratios are $0.5 \%$. The raw experimental data were processed using PbDAT (Version 1.21) and ISOPLOT (Version 2.06) [16,17], with age values calculated using conventional $\mathrm{U}$ decay constant values [18] and common $\mathrm{Pb}$ corrections following [19]. All uncertainties are reported at a $2 \sigma$ confidence level.

\section{Geological Setting of the Kolmozero-VoronyaBelt}

The Kolmozero-Voronya greenstone belt separates the Murmansk block from the Kola Province of the Fennoscandian Shield (Figure 1A). The belt has an approximately $140 \mathrm{~km}$ strike length and a width of up to $10-12 \mathrm{~km}$.

The history of the formation of the belt, as described in [20], includes the following events: formation of an island arc at 2.87-2.83 Ga; a break of 50 million years, and subsequent accretion of the island arc to the Murmansk continent; formation of an accretionary orogen $(2.78-2.76 \mathrm{Ga})$; probable collapse of the orogen with formation of post-orogenic (or possibly anorogenic) granite intrusions in the central and southern parts of the belt (2.74-2.72 Ga). The total time of the belt development was about $150 \mathrm{Ma}$ [20].

The structure of the belt is considered a monoclinal set of thrust sheets, with volcanics showing indications of oceanic and island arc magmatism [21,22]. The Archean supracrustal sequences of the belt comprise volcanics of tholeiite-komatiite and daciteandesite-basalt series (the Kolmozero series), and subordinate sedimentary rocks: pelites and sandstones (at the basement of the Kolmozero series and the Porosozero series) (Figure 1B,C). The total thickness of the cross-section is 1800-2000 m.

Supracrustal sequences in the northwestern part of the Kolmozero-Voronya belt were intruded by:

- Gabbro, pyroxenite, and peridotite co-magmatic to the Kolmozero series volcanics;

- Quartz porphyry intrusions of the gabbrodiorite-diorite-granodiorite-granite series (the $\mathrm{U}-\mathrm{Pb}$ age is $2.82-2.83 \mathrm{Ga}$, more details are given below);

- Plagiomicrocline and tourmaline granites (the U-Pb age of zircon from the tourmaline granite is $2451 \pm 60 \mathrm{Ma}$ [23]);

- $\quad$ Rare metal and tourmaline pegmatite veins (the $\mathrm{U}-\mathrm{Pb}$ age of microlite from the Cs-Li pegmatite Vasin-Mylk deposit is $2454 \pm 8 \mathrm{Ma}$ [24]);

- More than one generation of dolerite and picrite porphyry dykes of Proterozoic and possibly Paleozoic age. 
The rocks of the Kolmozero-Voronya belt were metamorphosed twice under conditions of the lower amphibolite facies: in the Neoarchean (2.7-2.8 Ga) and Paleoproterozoic $(1.9-1.8 \mathrm{Ga})[25,26]$. The PT-parameters of the early metamorphism were $\mathrm{T} \sim 600{ }^{\circ} \mathrm{C}$, $\mathrm{P}=3-4 \mathrm{kbar}$. At the late stage of metamorphism, the temperature was a little lower $\left(530^{\circ} \mathrm{C}\right.$ on the average), but pressure was higher ( $5.5 \mathrm{kbar})$ [26]. In the northwestern part of the belt, the mineral associations of the late metamorphic stage only partly replaced the early stage associations (paramorphoses of kyanite after andalusite, decomposition of cordierite in the outer parts of the grains (Figure 2), re-crystallization of biotite and muscovite).

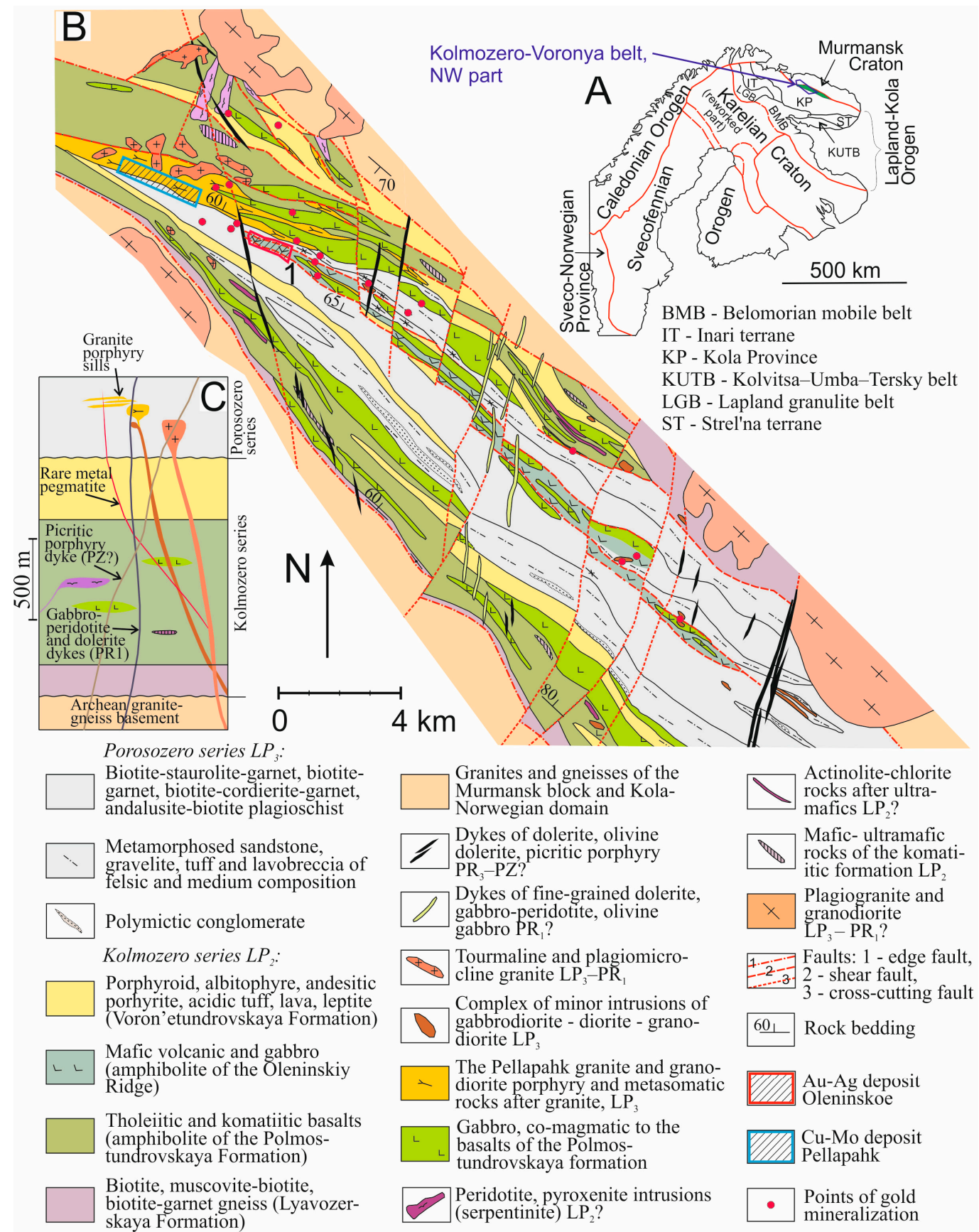

Figure 1. (A) Position of the Kolmozero-Voronya belt in the schematic tectonic map of the Fennoscandian Shield, modified from reference [27]. (B) Schematic geological map of the northwestern part of the Kolmozero-Voronya greenstone belt, modified from reference [28]. (C) Schematic stratigraphic column of the belt. 

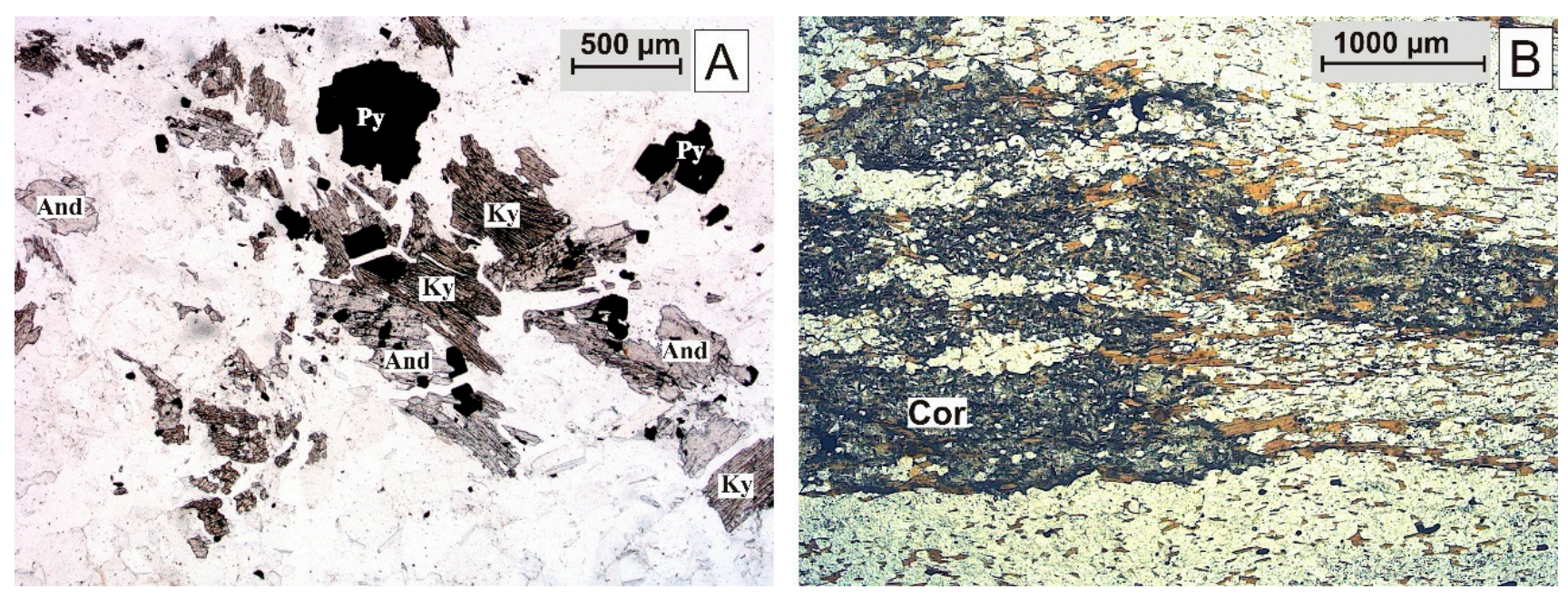

Figure 2. Paramorphoses of kyanite after andalusite in quartz-muscovite-kyanite schist (A) and decomposition of cordierite in biotite-cordierite plagioschist (B) as a result of the Early Proterozoic metamorphism. Thin section photo, plane polarized light. And—andalusite; Cor—cordierite; Ky—kyinite; Py—pyrite.

Three main fault systems are defined in the belt (Figure 1B) [29-31]. Deep faults of a NW direction along the boundaries of the belt comprise the first system. The second system unites strike-slip faults and shears of a NW up to latitudinal direction. These faults separate volcanic-sedimentary rock series or cut the stratigraphic boundaries at an acute angle of $5-15^{\circ}$. The faults of the second system can be traced for a few kilometers; the shears control zones of rock alteration [32]. The third fault system includes faults of a NE up to sub-meridional direction, which divide the belt into a number of blocks displaced for hundreds of meters. The faults of the third system are often marked by dolerite and picrite porphyry dykes (Figure 1).

\section{Results}

\subsection{Mineral Deposits Associated with the Granite Porphyry Intrusions}

More than 20 intrusions of the gabbrodiorite-diorite-granodiorite-granite porphyry series are located in the NW part of the belt. The rocks of mafic and intermediate composition form mainly small differentiated intrusions with the long axis less than $1000 \mathrm{~m}$. More acidic rocks (granodiorite and granite porphyry) can form bigger intrusions up to $8 \mathrm{~km}$ long and $1.5 \mathrm{~km}$ wide (Figure 1). The biggest intrusion at Pellapahk hosts a Cu-Mo deposit. Granite porphyry also forms sills in metavolcanics and metasediments in the central part and northern flank of the belt (Figure 1). The Oleninskoe gold-silver deposit is associated with granite porphyry sills in the Oleny Ridge amphibolite.

\subsubsection{The Pellapahk Cu-Mo Porphyry Deposit}

The Pellapahk granite porphyry intrusion is of elongated form, orientated according to the general strike of the belt: in the southeast, it splits into a number of thin granite porphyry sills (Figure 1B). The granite porphyry intrudes mafic and intermediate volcanics of the Kolmozero series and high-alumina primary sedimentary rocks of the Porosozero series. Xenoliths of the high-alumina gneiss were noted in the southern part of the intrusion. In the north, the granite porphyry intrusion is cut by younger intrusions of tourmaline plagiomicrocline granite. The intrusions and the surrounding country metavolcanic-sedimentary rocks are crossed by numerous dykes of pyroxenite, dolerite, picrite porphyry, and by pegmatite veins (Figures 3 and 4). 


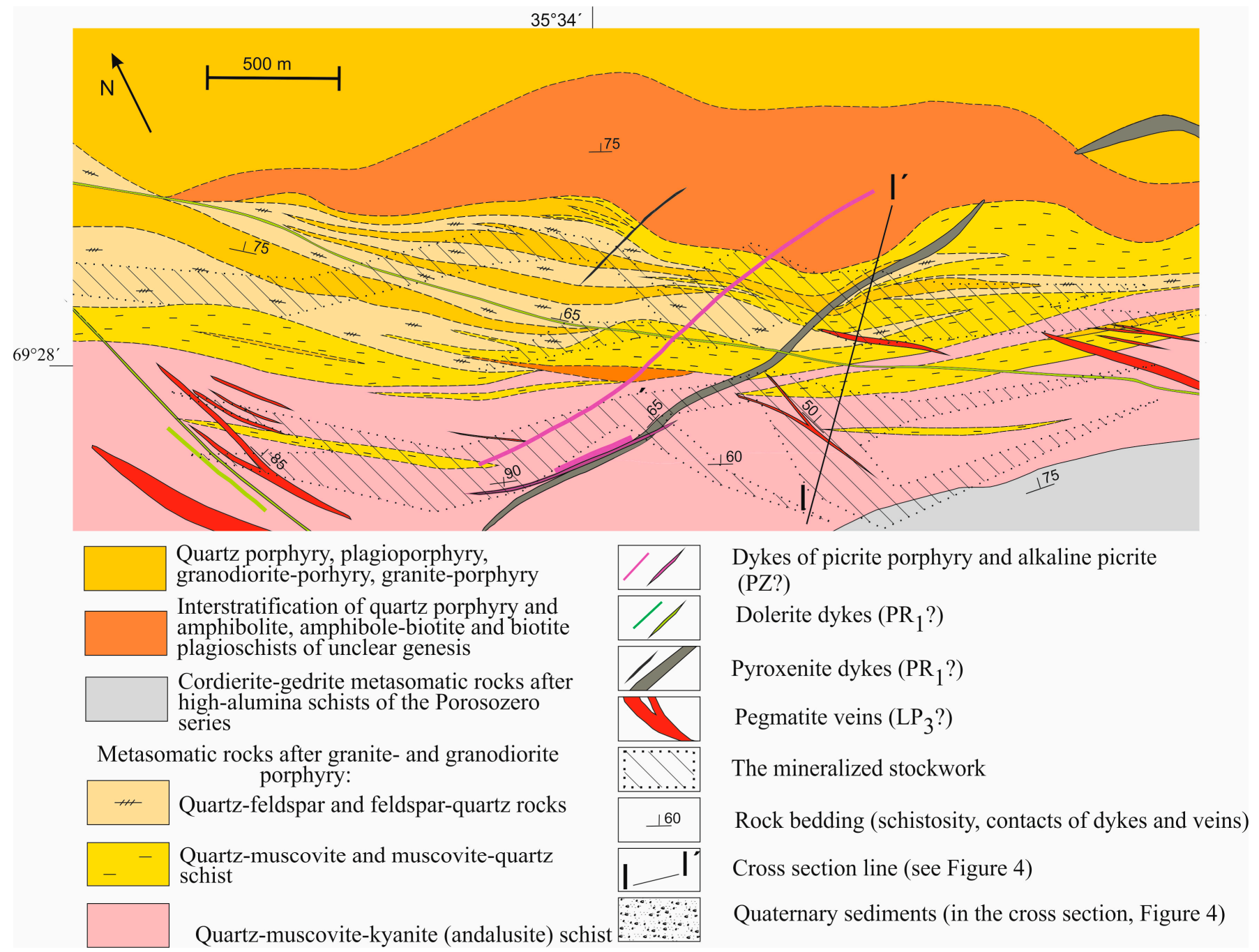

Figure 3. Schematic geological map of the Pellapahk Cu-Mo deposit, modified from Reference [9].

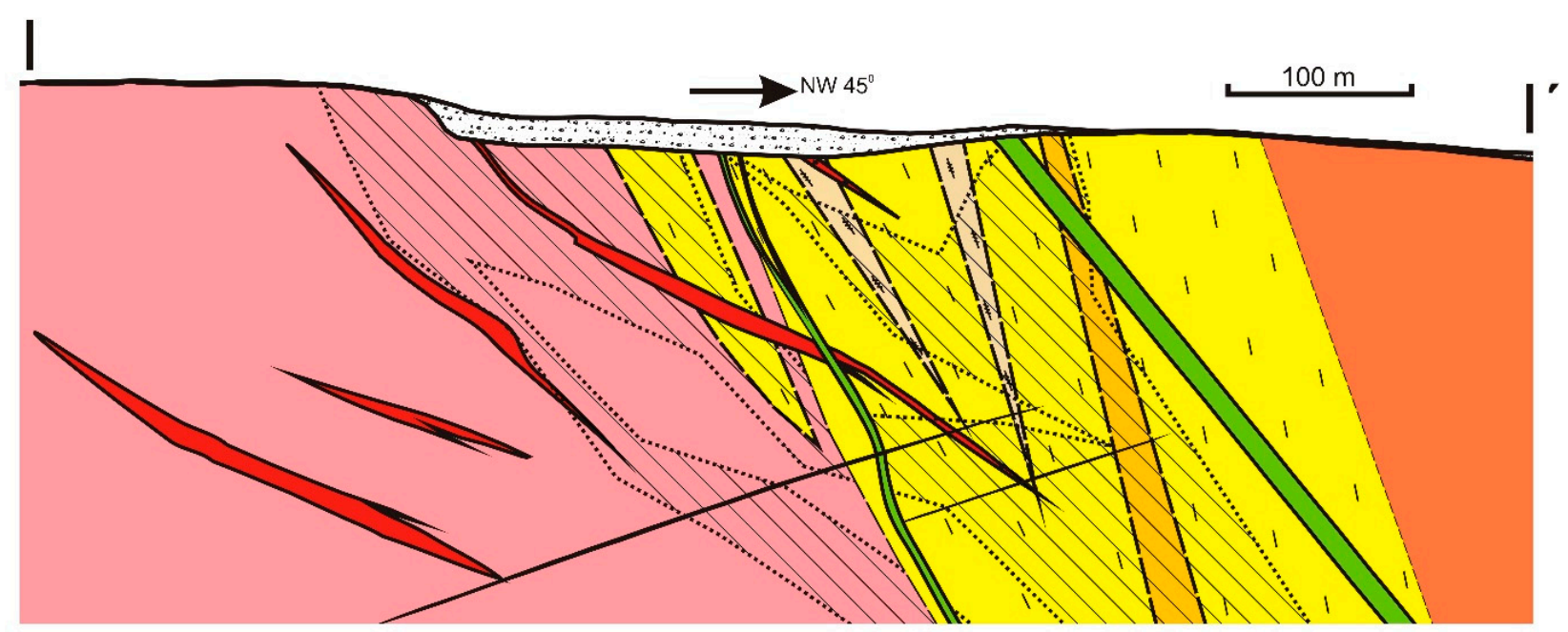

Figure 4. Cross-section of the mineralized stockwork of the Pellapahk Cu-Mo deposit along I-I' line, modified from Reference [9]. See Figure 2 for Legend. 
The age of zircon from the Pellapahk granite porphyry, defined by the U-Pb method, is $2828 \pm 8 \mathrm{Ma}$ [10]; i.e., the granite porphyry crystallized at the late stage of formation of the volcanic-sedimentary sequence, before the main metamorphic event (2770 $\pm 40 \mathrm{Ma})$ [25].

The rock-forming minerals in granite porphyry are quartz, $40-45 \mathrm{vol} . \%$; oligoclase, $25-35 \%$; muscovite, $10-15 \%$; biotite, $5-10 \%$; and microcline up to $5 \%$. It is a fine-grained rock, with quartz and oligoclase phenocrysts up to $2 \mathrm{~mm}$ in size. The accessory minerals are titanite, ilmenite, rutile, tourmaline, apatite, and scheelite. The sulfides are pyrite, pyrrhotite, chalcopyrite, rare sphalerite and pentlandite.

Granite porphyry of the Pellapahk intrusion belongs to the calc-alkaline series (Table 1, Figure 5). Chemical composition of the rock corresponds to metaluminous I-type granite [33,34].

Table 1. Chemical composition ( $w \mathrm{t} \%$ ) of granite porphyry and altered rocks of the Pellapahk intrusion.

\begin{tabular}{ccccccccccc}
\hline Sample \# & $\mathbf{A K - 1 0 7}$ & $\mathbf{A K - 1 2 1}$ & $\mathbf{A K - 2 8 9}$ & $\mathbf{A K - 2 9 2}$ & $\mathbf{A K - 2 9 3}$ & AK-721 & C-904 & AK-120 & AK-130 & C-902 \\
\hline $\mathrm{SiO}_{2}$ & 71.62 & 68.57 & 72.48 & 72.65 & 72.67 & 73.23 & 71.68 & 79.30 & 79.87 & 75.50 \\
$\mathrm{TiO}_{2}$ & 0.23 & 0.36 & 0.18 & 0.24 & 0.26 & 0.29 & 0.16 & 0.12 & 0.23 & 0.21 \\
$\mathrm{Al}_{2} \mathrm{O}_{3}$ & 14.56 & 15.16 & 14.26 & 14.46 & 14.45 & 12.20 & 13.19 & 12.77 & 12.85 & 12.85 \\
$\mathrm{Fe}_{2} \mathrm{O}_{3}$ & 0.37 & 2.12 & 0.78 & 0.55 & 1.04 & n.a. & 0.84 & 0.34 & 0.27 & 2.22 \\
$\mathrm{FeO}$ & 1.52 & 1.08 & 1.57 & 1.98 & 0.86 & n.a. & 1.61 & 0.27 & 0.37 & 1.65 \\
$\mathrm{FeO}$ & 1.85 & 2.99 & 2.27 & 2.48 & 1.80 & 3.44 & 2.37 & 0.58 & 0.61 & 3.65 \\
$\mathrm{MnO}$ & 0.05 & 0.02 & 0.06 & 0.04 & 0.02 & 0.22 & 0.04 & 0.01 & 0.01 & 0.02 \\
$\mathrm{MgO}$ & 0.84 & 1.16 & 1.64 & 0.86 & 0.58 & 1.49 & 0.96 & 0.44 & 0.39 & 0.86 \\
$\mathrm{CaO}$ & 2.46 & 1.70 & 3.88 & 3.18 & 2.04 & 2.55 & 3.09 & 0.26 & 0.02 & 0.35 \\
$\mathrm{Na}_{2} \mathrm{O}$ & 4.02 & 5.11 & 2.14 & 3.11 & 4.78 & 2.19 & 3.60 & 0.52 & 0.25 & 0.57 \\
$\mathrm{~K}_{2} \mathrm{O}$ & 2.50 & 1.91 & 1.38 & 1.70 & 1.86 & 0.68 & 2.62 & 3.64 & 3.45 & 2.62 \\
$\mathrm{P}_{2} \mathrm{O} 5$ & 0.10 & 0.04 & 0.07 & 0.08 & 0.05 & 0.12 & 0.08 & 0.03 & 0.07 & 0.09 \\
$\mathrm{~S}$ & 0.44 & 1.70 & 0.22 & 0.00 & 0.33 & 1.20 & 0.57 & 0.07 & 0.05 & 1.66 \\
$\mathrm{LOI}$ & 0.84 & 1.32 & 1.90 & 1.25 & 1.48 & 2.12 & 0.89 & 2.38 & 2.25 & 1.74 \\
$\mathrm{CO}_{2}$ & 0.01 & 0.00 & 0.05 & 0.05 & 0.06 & $<0.10$ & 0.74 & 0.00 & 0.04 & 0.00 \\
$\mathrm{Total}$ & 99.56 & 100.25 & 100.61 & 100.15 & 100.48 & 99.73 & 100.07 & 100.15 & 100.12 & 100.34 \\
\hline
\end{tabular}

Notes: AK-107, AK-121, AK-289, AK-292, AK-293, AK-721-granite porphyry; C-904-granite porphyry with quartz-epidote-carbonate veinlets; AK-120, AK-130, C-902-quartz-muscovite-kyanite schist. n.a. $=$ not assayed. $\mathrm{FeO}^{*}=\mathrm{FeO}+0.9^{*} \mathrm{Fe}_{2} \mathrm{O}_{3}$.
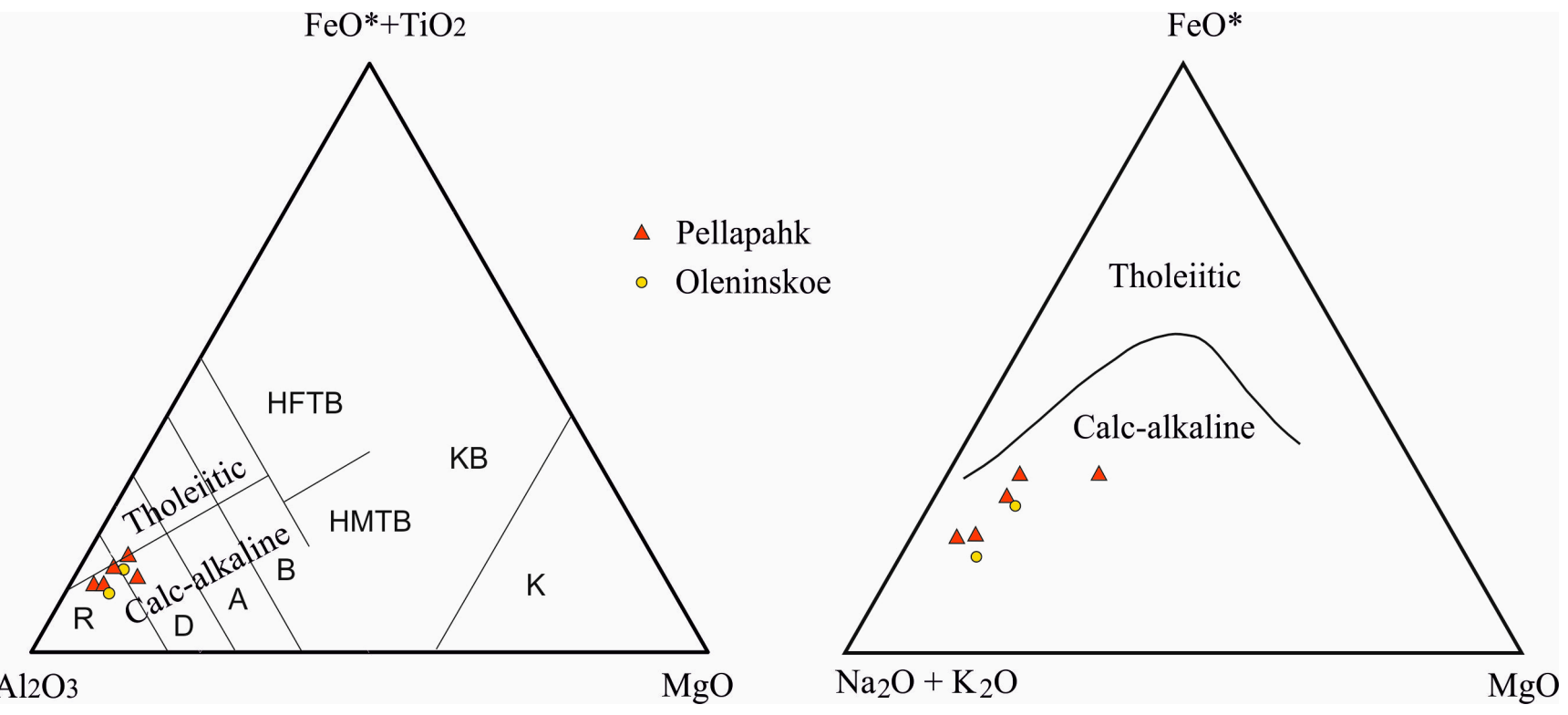

Figure 5. Composition of the Pellapahk and Oleninskoe granite-porphyry in the petrochemical diagrams $\left(\mathrm{FeO}^{*}=\mathrm{FeO}+0.9 * \mathrm{Fe}_{2} \mathrm{O}_{3}\right)$.

REE spectra (Figure 6), drawn with data from Table 2 and Table 5, are similar to the REE spectrum of I-type granite, formed under conditions of subduction and island arc [34]. 


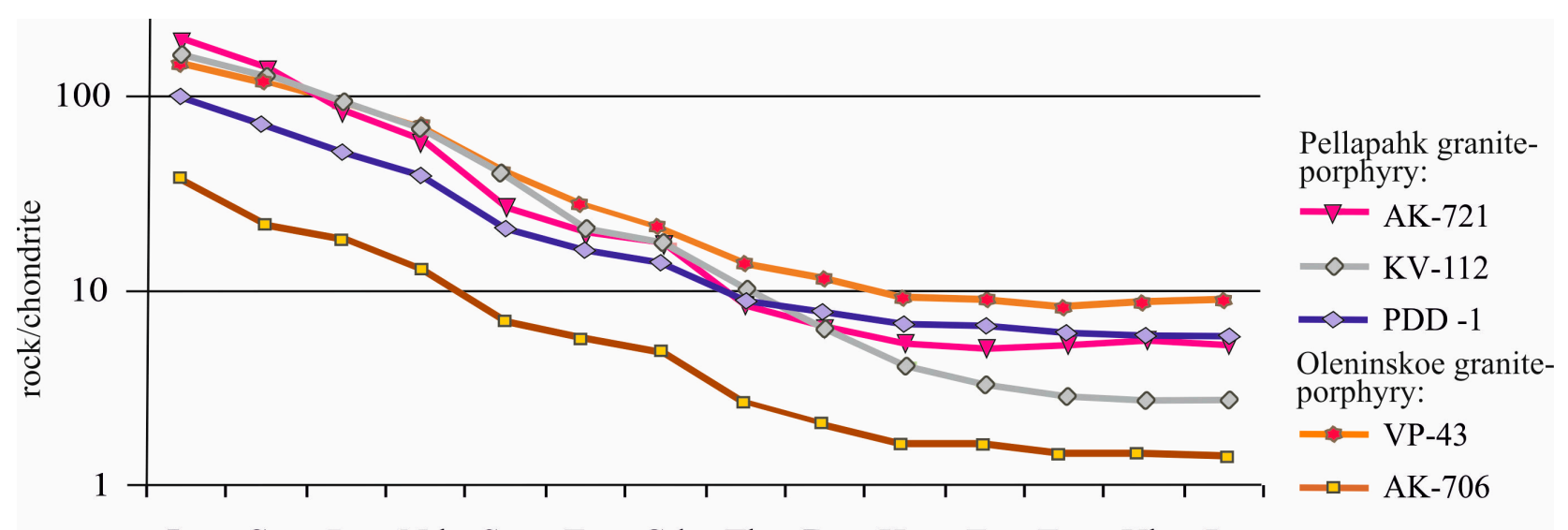

$\mathrm{La} \quad \mathrm{Ce} \quad \mathrm{Pr} \quad \mathrm{Nd} \quad \mathrm{Sm} \mathrm{Eu}$ Gd $\mathrm{Tb}$ Dy $\mathrm{Ho}$ Er $\mathrm{Tm} \quad \mathrm{Yb} \quad \mathrm{Lu}$

Figure 6. REE spectra for granite porphyry of the Pellapahk Cu-Mo and the Oleninskoe Au-Ag deposits, normalized by chondrite [35].

Table 2. ICP-MS data for granite porphyry (AK-721), and mineralized (KV-112, PDD-1) metasomatic rocks of the Pellapahk deposit, $\mathrm{g} / \mathrm{t}$.

\begin{tabular}{|c|c|c|c|c|c|c|c|}
\hline Element & AK-721 & KV-112 & PDD-1 & Element & AK-721 & KV-112 & PDD-1 \\
\hline $\mathrm{Li}$ & 184 & 57 & 17 & $\mathrm{Ba}$ & 227 & 507 & 664 \\
\hline Be & 0.86 & 1.53 & 0.52 & $\mathrm{La}$ & 46 & 41 & 25 \\
\hline $\mathrm{Sc}$ & 1.70 & 4.38 & 2.67 & $\mathrm{Ce}$ & 93 & 82 & 45 \\
\hline $\mathrm{V}$ & 39 & 32 & 25 & $\operatorname{Pr}$ & 7.96 & 9.03 & 5.05 \\
\hline $\mathrm{Cr}$ & 826 & 164 & 164 & $\mathrm{Nd}$ & 28 & 34 & 18.4 \\
\hline $\mathrm{Co}$ & 6.31 & 13.5 & 7.17 & $\mathrm{Sm}$ & 4.25 & 6.07 & 3.17 \\
\hline $\mathrm{Ni}$ & 47 & 16.7 & 13.2 & $\mathrm{Eu}$ & 1.12 & 1.22 & 0.90 \\
\hline $\mathrm{Cu}$ & 26 & 1150 & 1516 & $\mathrm{Gd}$ & 3.65 & 3.88 & 2.71 \\
\hline $\mathrm{Zn}$ & 51 & 45 & 21 & $\mathrm{~Tb}$ & 0.33 & 0.40 & 0.31 \\
\hline $\mathrm{Ga}$ & 27 & 20 & 14.2 & Dy & 1.79 & 1.62 & 1.87 \\
\hline As & 10.0 & 0.97 & 6.63 & Ho & 0.31 & 0.24 & 0.36 \\
\hline Se & 0.33 & 3.51 & 1.26 & Er & 0.90 & 0.55 & 1.03 \\
\hline $\mathrm{Rb}$ & 59 & 166 & 168 & $\mathrm{Tm}$ & 0.14 & 0.07 & 0.15 \\
\hline $\mathrm{Sr}$ & 393 & 139 & 537 & $\mathrm{Yb}$ & 1.02 & 0.47 & 0.95 \\
\hline $\mathrm{Y}$ & 12.9 & 6.05 & 10.5 & $\mathrm{Lu}$ & 0.14 & 0.07 & 0.14 \\
\hline $\mathrm{Zr}$ & 171 & 145 & 137 & $\mathrm{Hf}$ & 3.27 & 4.36 & 3.02 \\
\hline $\mathrm{Nb}$ & 4.30 & 4.40 & 6.75 & $\mathrm{Ta}$ & 0.31 & 0.30 & 0.37 \\
\hline Mo & 3.52 & 167 & 173 & W & 1.61 & 31.02 & 12.96 \\
\hline $\mathrm{Ag}$ & 1.30 & 2.30 & 3.16 & $\mathrm{Tl}$ & 0.85 & 2.46 & 0.55 \\
\hline $\mathrm{Cd}$ & 0.22 & 0.40 & n.a. & $\mathrm{Pb}$ & 153 & 115 & 15 \\
\hline Sn & 0.98 & 5.32 & 1.57 & $\mathrm{Bi}$ & 0.32 & 11.3 & 2.65 \\
\hline $\mathrm{Sb}$ & 0.44 & 1.91 & 2.98 & Th & 8.38 & 7.66 & 6.67 \\
\hline $\mathrm{Te}$ & 0.17 & 0.61 & 0.18 & $\mathrm{U}$ & 2.15 & 3.19 & 1.91 \\
\hline Cs & 14.7 & 6.25 & 2.87 & - & - & - & - \\
\hline
\end{tabular}

n.a. = not assayed.

The zone of intense rock alteration has a total thickness of more than $700 \mathrm{~m}$ and follows the contact of the granite porphyry with high-alumina gneiss (Figure 3). The general zoning of the alteration is the following (from north to south): (0) slightly altered granite porphyry; (1) quartz-microcline rock; (2) muscovite schist; (3) muscovite-kyanite (or/and andalusite) schist; (4) altered (gedrite, cordierite) high-alumina schist, and (5) nonaltered biotite-andalusite schist (Figure 3). Rocks in zones (1)-(3) formed after granite porphyry, and in (4), after the high-alumina schist (5) of the Porosozero series.

Muscovite and muscovite-kyanite schists contain phenocrysts of quartz preserved from the primary porphyry ( $3-4 \mathrm{vol} . \%)$, newly formed porphyroblasts of andalusite and/or kyanite (up to $6-8 \mathrm{vol} . \%$ ), and pyrite metacrystals up to $3 \mathrm{~mm}$ in size (1-3 vol.\%). 
Alteration processes caused the decomposition of plagioclase and microcline, the formation of high-alumina minerals andalusite and kyanite (Figure 2A), and the replacement of biotite by muscovite in the granite porphyry. The muscovite and muscovite-kyanite schists have high $\mathrm{SiO}_{2}$ and $\mathrm{K}_{2} \mathrm{O}$ content, compared to the composition of the primary rock, but are poorer in $\mathrm{MgO}, \mathrm{CaO}$, and $\mathrm{Na}_{2} \mathrm{O}$ (Table 1 ).

All altered rocks contain sulfide mineralization. Cordierite-gedrite rock after highalumina schists contains disseminated pyrrhotite in intergrowths with chalcopyrite, pyrite, rarely sphalerite, arsenopyrite, cobaltite-gersdorfite, and pentlandite; the main oxide minerals are ilmenite and magnetite. Muscovite, muscovite-kyanite schists and quartzmicrocline rocks after granite porphyry contain pyrite mineralization up to 3 vol. $\%$ with minor chalcopyrite, pyrrhotite, and sphalerite. Rutile is the main oxide mineral in these rocks and replaces ilmenite.

The Cu-Mo mineralization comprises a stockwork of quartz and quartz-calciteepidote veinlets in the zone of alteration of granite porphyry. The stockwork was traced for 1500-1600 m along the strike; its width varies from 350 to $600 \mathrm{~m}$ (Figures 3 and 4). The mineralization was drilled down to a depth of $360 \mathrm{~m}$ in the NW part of the stockwork, and probably goes deeper [9].

Geochemical association of the metals in the mineralized altered rocks in the stockwork includes $\mathrm{Mo}, \mathrm{Cu}, \mathrm{Ag}, \mathrm{Bi}, \mathrm{W}$, Se, and $\mathrm{Sb}$ (Figure 7, Table 2). The content of $\mathrm{Cu}, \mathrm{Mo}, \mathrm{Bi}$, and $\mathrm{W}$ in the altered rocks is 10 or more times higher than in the primary granite porphyry.
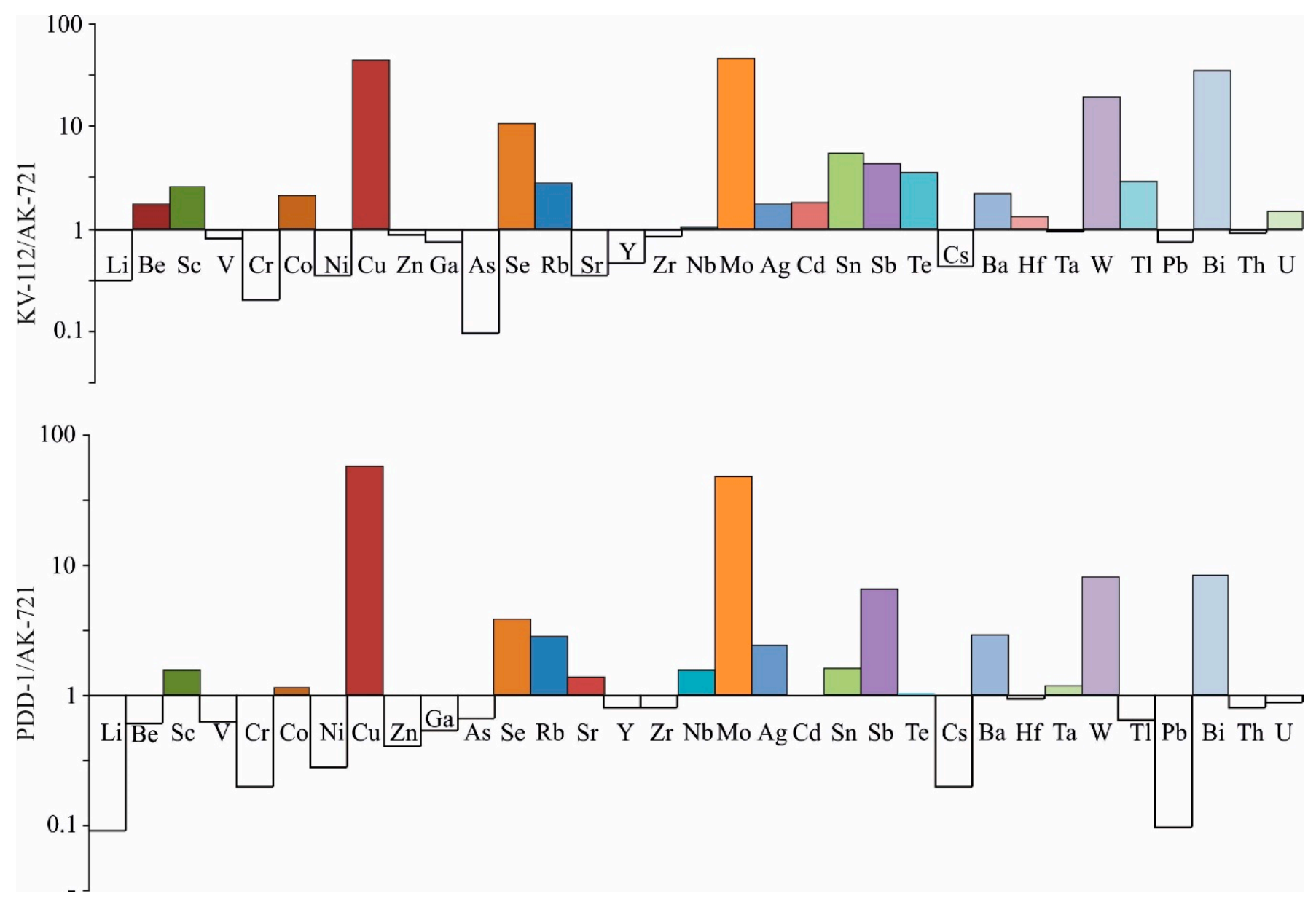

Figure 7. Trace elements spectra in the muscovite-kyanite schist (KV-112 and PDD-1) in the mineralized stockwork compared to the slightly altered granite porphyry (AK-721).

In the stockwork, the main ore minerals are pyrite, chalcopyrite, and rutile. Sporadic ore minerals are molybdenite, sphalerite, galena, tetrahedrite, pyrrhotite, cubanite, ilmenite, 
scheelite. The rare minerals are native bismuth, gudmundite, tennantite, löllingite, lillianite, and pentlandite $[9,36]$. The oxidation zone is not well developed in the deposit, but bornite and covellite were rarely noted to replace chalcopyrite in the outer parts of the grains.

Pyrite is the most abundant sulfide mineral both within the mineralized $\mathrm{Cu}-\mathrm{Mo}$ stockwork, and outside of it. Idiomorphic grains of pyrite are regularly disseminated in the rock groundmass, but the content of pyrite and the size of its grains (cubic crystals may reach $3 \mathrm{~mm}$ ) increase in the quartz-carbonate-epidote veinlets.

The main productive minerals are chalcopyrite and molybdenite. Chalcopyrite forms irregular grains up to $0.5 \mathrm{~mm}$ in the rock mass; it develops in fractures in pyrite grains and along cleavage in kyanite, but much more rarely in andalusite (Figure 8B).
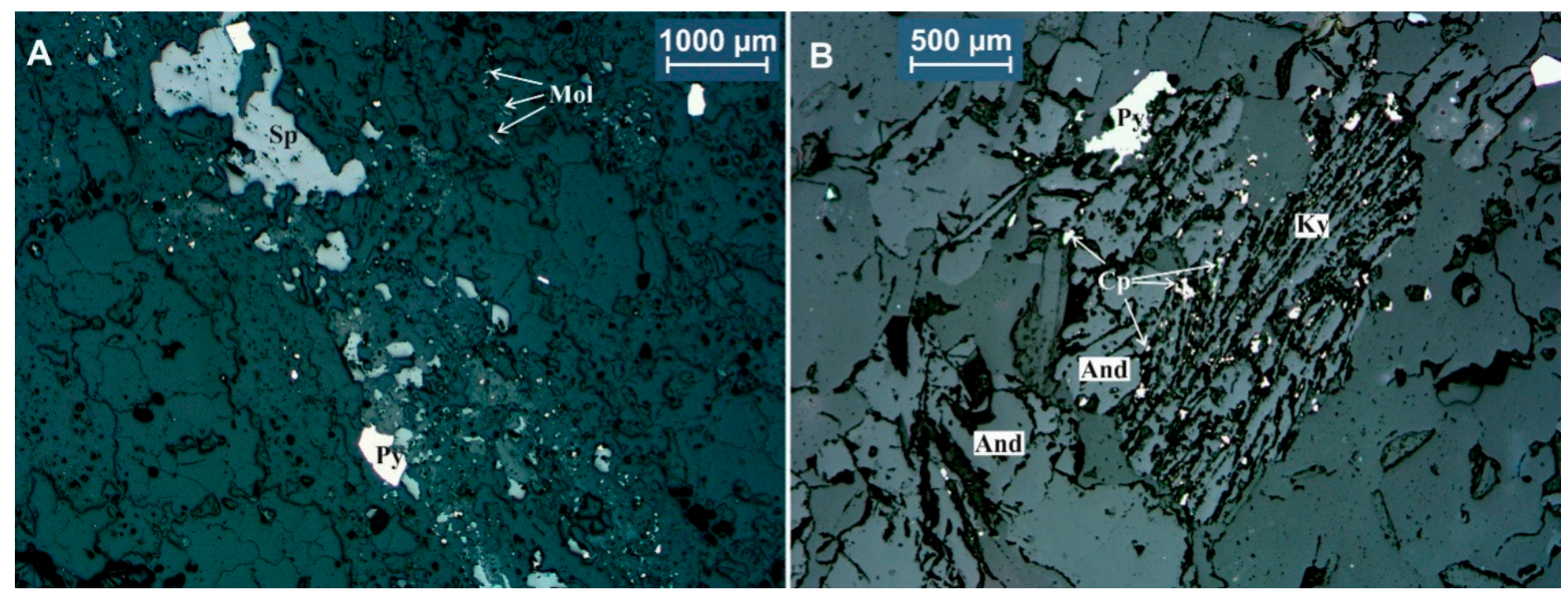

Figure 8. Quartz-calcite-epidote veinlet with sphalerite-pyrite mineralization (A) and kyanite with disseminated chalcopyrite along the cleavage, Pellapahk Cu-Mo deposit (B). Polished section photo, plane polarized light. Cp-chalcopyrite; Mol—molybdenite; Py—pyrite; Sp—sphalerite.

Molybdenite forms fine flakes (mainly $0.05-0.1 \mathrm{~mm}$, rarely up to $0.5 \mathrm{~mm}$ ) along cleavage in muscovite or along quartz grain boundaries. Chains of molybdenite flakes cross pyrite crystals, chalcopyrite, and sphalerite grains [36].

Galena and sphalerite are rare in the rock groundmass, but their content significantly increases in the quartz-epidote-calcite veinlets. The rare minerals of As, $\mathrm{Sb}$, and Bi (fahlore, gudmundite, lillianite) are associated mainly with galena.

\subsubsection{The Oleninskoe Au-Ag Deposit}

The Oleninskoe Au-Ag deposit is located at the northwestern thinning of the Oleny Ridge amphibolite strata (Figure 1) in a shear zone of northwest strike [37-39]. The amphibolite and high-alumina metasedimentary schist host numerous granite porphyry sills with a thickness of 0.1-6.0 $\mathrm{m}$ (Figures 9 and 10).

The Oleny Ridge amphibolite borders biotite-andalusite gneiss of the Porosozero series in the south, and a stratum of alternation of amphibolite, biotite-cordierite, and biotite-andalusite gneisses in the north. Both southern and northern contacts are tectonic.

The latest rocks in the deposit are granite-pegmatite veins, which cut all rocks, including those that are mineralized. The thickest veins can be traced in a NW direction for hundreds of meters (Figure 9).

The rock in the sills is very fine-grained; the size of plagioclase, quartz grains, and biotite and muscovite flakes in the groundmass is less than $0.05 \mathrm{~mm}$; quartz phenocrysts are $<0.5 \mathrm{~mm}$. Phenocrysts of plagioclase were not found. 


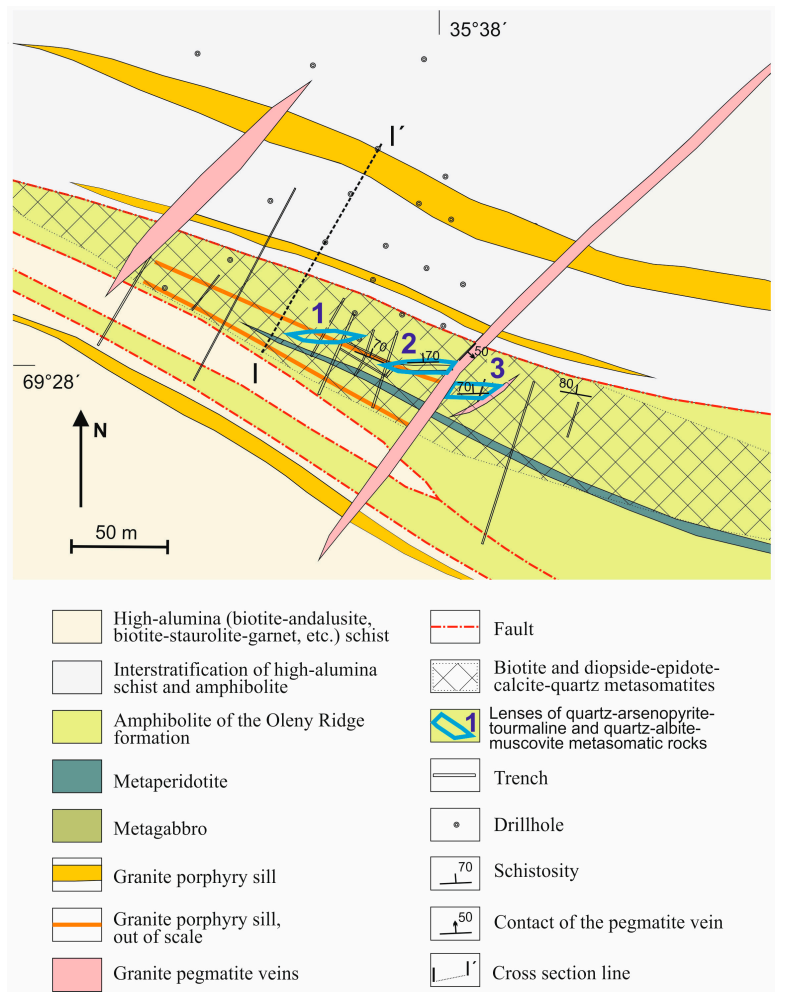

Figure 9. Schematic geological map of the Oleninskoe deposit, modified from References [28,37].

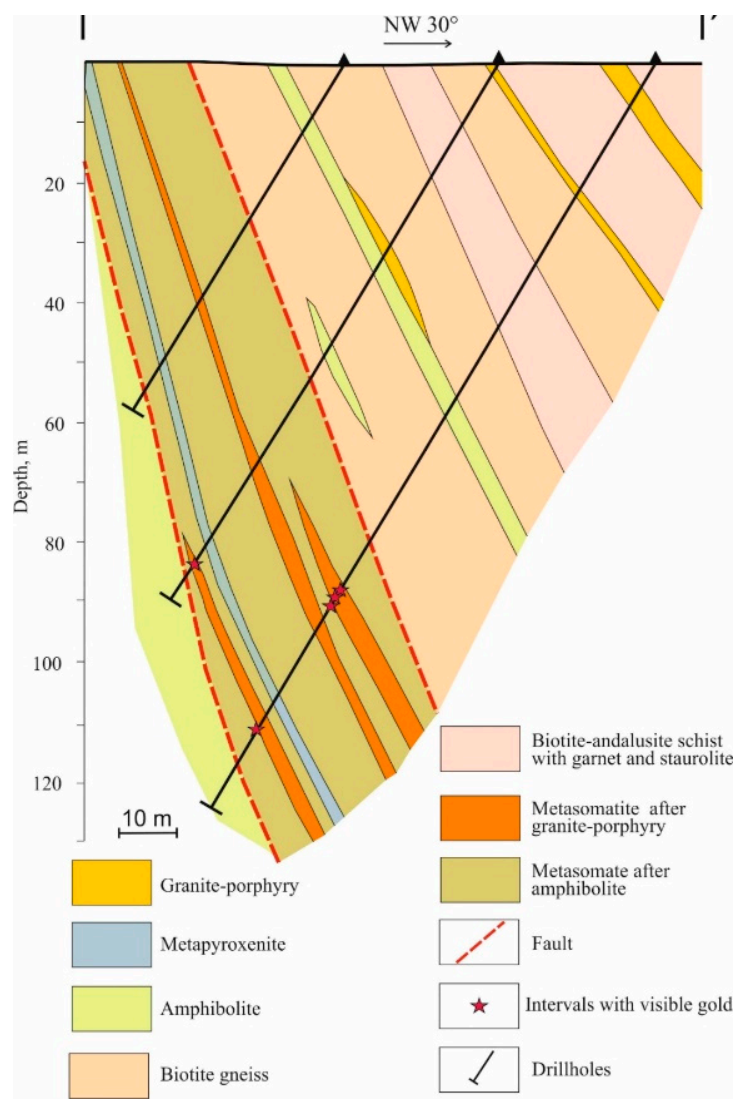

Figure 10. Schematic cross-section of the main mineralized zone of the Oleninskoe deposit along I-I' line (Figure 9). 
The age of the granite porphyry sill in the Oleninskoe deposit was defined by a $\mathrm{U}-\mathrm{Pb}$ geochronological study of zircons. Zircons (sample AK-706) are long-prismatic, idiomorphic and sub-idiomorphic, from 50 to $100 \mu \mathrm{m}$ in size, of brownish color, and with fine growth zoning suggesting a magmatic origin. The zircon fractions yield a discordia with an upper intercept at $2817 \pm 9 \mathrm{Ma}(\mathrm{MSWD}=0.54$, Table 3, Figure 11) that represents the crystallization age of the granite porphyry sill.

Table 3. Results of $\mathrm{U}-\mathrm{Pb}$ geochronological studies of zircons from the Oleninskoe deposit.

\begin{tabular}{|c|c|c|c|c|c|c|}
\hline Sample \# & \multirow{2}{*}{ Weight, mg } & \multirow{2}{*}{$\mathrm{Pb}(\mathrm{ppm})$} & \multirow{2}{*}{$\mathrm{U}(\mathrm{ppm})$} & \multicolumn{3}{|c|}{ Isotope Ratios } \\
\hline Fraction \# & & & & ${ }^{206} \mathrm{~Pb} /{ }^{204} \mathrm{~Pb}$ * & ${ }^{207} \mathrm{~Pb} /{ }^{206} \mathrm{~Pb}$ * & ${ }^{208} \mathrm{~Pb} /{ }^{206} \mathrm{~Pb}$ * \\
\hline AK-706/1 & 0.3 & 250 & 483 & 1250 & $0.2040 \pm 0.0002$ & $0.1034 \pm 0.0002$ \\
\hline $\mathrm{AK}-706 / 2$ & 0.3 & 65 & 130 & 796 & $0.2090 \pm 0.0004$ & $0.1309 \pm 0.0003$ \\
\hline AK-706/3 & 0.2 & 109 & 192 & 1552 & $0.2061 \pm 0.0002$ & $0.1109 \pm 0.0002$ \\
\hline AK-706/4 & 0.2 & 178 & 355 & 1271 & $0.2033 \pm 0.0003$ & $0.1099 \pm 0.0003$ \\
\hline Sample \# & \multicolumn{2}{|c|}{ Isotope Ratios } & \multirow{2}{*}{ Rho } & \multicolumn{3}{|c|}{ Age, Ma } \\
\hline Fraction \# & ${ }^{206} \mathrm{~Pb} /{ }^{238} \mathrm{U}$ & ${ }^{207} \mathrm{~Pb} /{ }^{235} \mathrm{U}$ & & ${ }^{206} \mathrm{~Pb} /{ }^{238} \mathrm{U}$ & ${ }^{207} \mathrm{~Pb} /{ }^{235} \mathrm{U}$ & ${ }^{207} \mathrm{~Pb} /{ }^{206} \mathrm{~Pb}$ \\
\hline AK-706/1 & $0.4559 \pm 0.0022$ & $12.234 \pm 0.061$ & 0.93 & $2422 \pm 12$ & $2623 \pm 13$ & $2782 \pm 3$ \\
\hline AK-706/2 & $0.4293 \pm 0.0030$ & $11.497 \pm 0.072$ & 0.91 & $2303 \pm 16$ & $2564 \pm 20$ & $2778 \pm 6$ \\
\hline AK-706/3 & $0.5080 \pm 0.0025$ & $13.820 \pm 0.069$ & 0.93 & $2648 \pm 13$ & $2742 \pm 14$ & $2812 \pm 5$ \\
\hline AK-706/4 & $0.4410 \pm 0.0023$ & $11.802 \pm 0.064$ & 0.91 & $2355 \pm 14$ & $2589 \pm 16$ & $2777 \pm 5$ \\
\hline
\end{tabular}

${ }^{*}$ Isotope ratios are corrected for the blank and common lead. Rho- the correlation coefficient of the $207 \mathrm{~Pb} / 235 \mathrm{U}-206 \mathrm{~Pb} / 238 \mathrm{U}$ ratios.

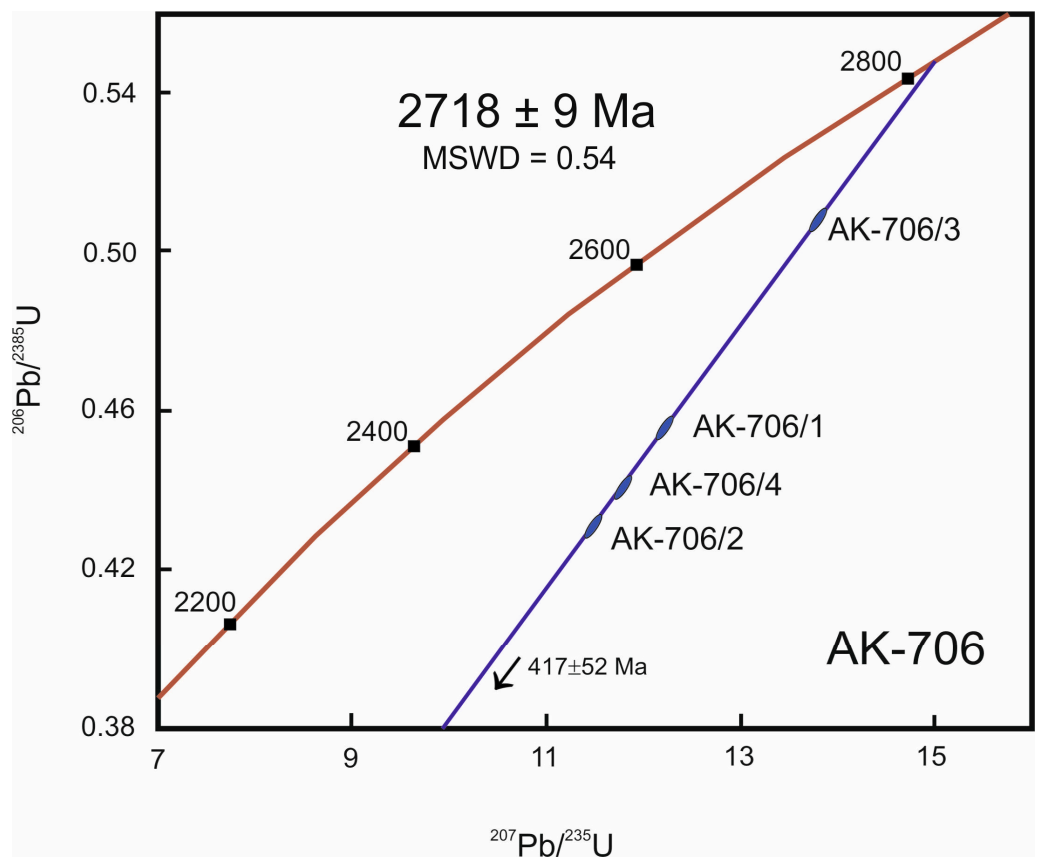

Figure 11. Diagram with concordia for granite porphyry from the Oleninskoe deposit.

The chemical composition of the non-altered granite porphyry sills is generally similar to the granite porphyry of the Pellapahk intrusion (Table 4, Figure 5), and the granite porphyry from the Oleninskoe deposit belongs to the series of calc-alkaline I-type granites.

The spectrum of REE in sample AK-706 (Oleninskoe) differs in the lower content of REE (Figure 6), but the form of the curve is very similar to the one in the REE spectra of the Pellapahk granite-porphyry.

The mineralized zone consists of a number of ore lenses within an area of $900 \times 50 \mathrm{~m}$ (Figure 9). The zone is orientated according to the general strike of the rocks. The ore lenses are up to $3.5 \mathrm{~m}$ thick ( $1.5 \mathrm{~m}$ on average) with the length up to $50 \mathrm{~m}$; they form an 
echelon-like series of lenticular bodies, cutting general schistosity in the host rocks at an acute angle of $10-15^{\circ}$ (Figure 9). Three lenses are outcropped on the surface, but drilling shows their number is more than three. The mineralization is traced by drilling down to a depth of $200 \mathrm{~m}$, and goes deeper. The thickness of the ore intervals and Au grades increase with the depth [31]. The weighted average gold content is $7.6 \mathrm{~g} / \mathrm{t}$; inferred resources are estimated at $10 \mathrm{t}$ Au down to a depth of $100 \mathrm{~m}$ [13].

The amphibolite is intensely altered. Diopsidization (diopside-zoisite, diopsideepidote, diopside-epidote-carbonate, diopside-epidote-garnet associations) and biotitization cover the whole mineralized zone, and quartz-arsenopyrite-tourmaline metasomatic rocks are spatially confined to the ore lenses. Granite porphyry is turned to quartzalbite-muscovite, quartz-arsenopyrite-tourmaline, and quartz metasomatic rocks: the latter formed the most recently and very locally (ellipsoidal bodies, $\sim 30 \times 10 \mathrm{~cm}$ ) (Figure 12). All kinds of metasomatic rocks and the zoning of alteration can be seen in lens 2, outcropped with a trench along the strike (Figure 12).

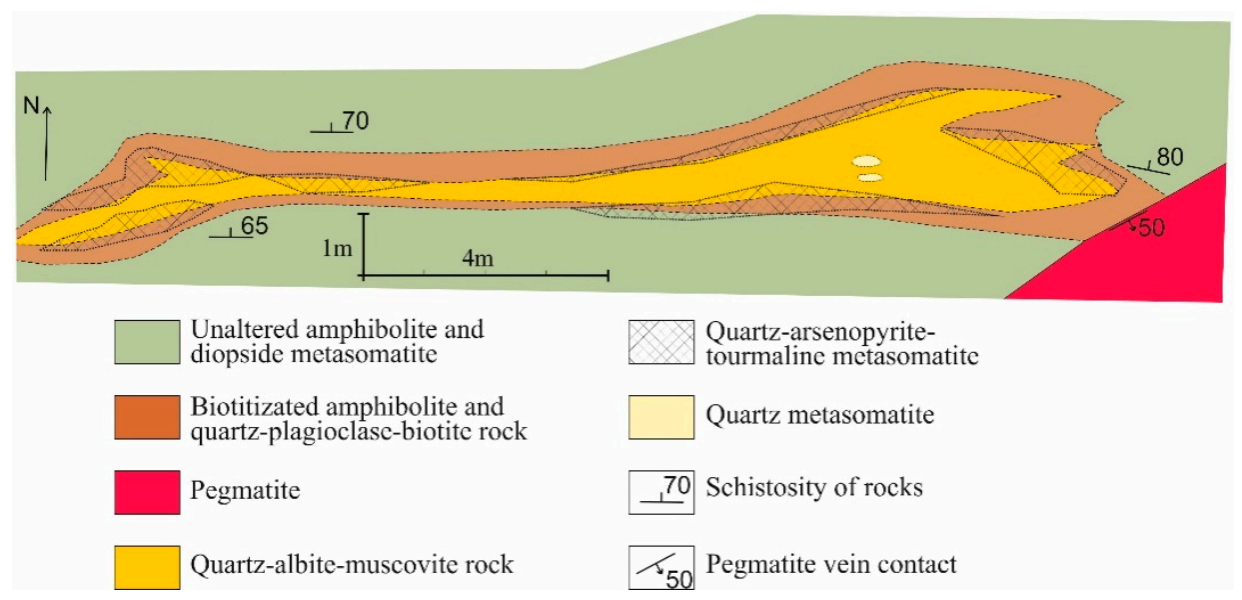

Figure 12. Scheme of zoning of metasomatic rocks in lens 2 (see Figure 9), logging of the trench.

Table 4. Chemical composition (wt $\%$ ) of granite porphyry and altered rocks of the Oleninskoe deposit.

\begin{tabular}{|c|c|c|c|c|c|c|c|c|c|}
\hline Sample \# & VP-10 & AK-706 & AK-710 & AK-712 & AK-900K & AK-900C & AK-900T & AK-707 & AK-711 \\
\hline $\mathrm{SiO}_{2}$ & 69.53 & 71.56 & 64.22 & 59.53 & 61.07 & 65.58 & 55.93 & 62.38 & 92.55 \\
\hline $\mathrm{TiO}_{2}$ & 0.23 & 0.34 & 0.97 & 1.22 & 0.98 & 0.89 & 1.22 & 0.28 & 0.10 \\
\hline $\mathrm{Al}_{2} \mathrm{O}_{3}$ & 16.20 & 14.69 & 11.91 & 14.06 & 10.75 & 13.22 & 13.38 & 2.71 & 1.30 \\
\hline $\mathrm{Fe}_{2} \mathrm{O}_{3}$ & 0.48 & 0.00 & 1.62 & 3.48 & 4.25 & 2.32 & 5.44 & 7.99 & 0.00 \\
\hline $\mathrm{FeO}$ & 1.36 & 2.38 & 5.18 & 4.53 & 4.28 & 2.20 & 4.05 & 6.39 & 3.38 \\
\hline $\mathrm{FeO}^{*}$ & 1.79 & 2.38 & 6.64 & 7.66 & 8.11 & 4.29 & 8.95 & 13.58 & 3.38 \\
\hline $\mathrm{MnO}$ & 0.03 & 0.03 & 0.02 & 0.02 & 0.02 & 0.01 & 0.02 & 0.02 & 0.02 \\
\hline $\mathrm{MgO}$ & 1.18 & 1.18 & 0.19 & 0.33 & 0.24 & 0.24 & 0.22 & 0.43 & 0.18 \\
\hline $\mathrm{CaO}$ & 1.74 & 2.50 & 0.39 & 0.51 & 0.52 & 0.30 & 0.23 & 0.65 & 0.06 \\
\hline $\mathrm{Na}_{2} \mathrm{O}$ & 6.28 & 4.89 & 2.28 & 3.97 & 3.33 & 3.33 & 2.67 & 0.49 & 0.22 \\
\hline $\mathrm{K}_{2} \mathrm{O}$ & 1.56 & 1.01 & 1.94 & 1.68 & 1.06 & 1.82 & 2.30 & 0.26 & 0.07 \\
\hline $\mathrm{P}_{2} \mathrm{O}_{5}$ & 0.06 & 0.07 & 0.42 & 0.37 & 0.19 & 0.49 & 0.28 & 0.46 & 0.05 \\
\hline S & 0.01 & 0.07 & 1.15 & 2.93 & 3.47 & 0.54 & 4.27 & 3.57 & 0.27 \\
\hline LOI & 0.84 & 0.84 & 3.04 * & 1.53 & 1.57 & 7.75 * & $3.46^{*}$ & $4.53 *$ & 1.13 \\
\hline $\mathrm{CO}_{2}$ & $<0.10$ & $<0.10$ & $<0.10$ & $<0.10$ & $<0.10$ & $<0.10$ & $<0.10$ & $<0.10$ & $<0.10$ \\
\hline Total & 99.50 & 99.56 & 99.85 & $94.16^{* *}$ & $91.73^{* *}$ & 98.69 & $93.47^{* *}$ & $90.16^{* *}$ & 99.33 \\
\hline $\mathrm{Ag}$ (ppm) & n.a. & 0.80 & 20.72 & 17.49 & 110.38 & 9.96 & 11.17 & 96.50 & 114.14 \\
\hline $\mathrm{Au}(\mathrm{ppm})$ & n.a. & $<0.004$ & 3.29 & 0.15 & 2.36 & 1.62 & 0.24 & 3.16 & 90.93 \\
\hline
\end{tabular}

* High loss on ignition is connected with carbonaceous matter in the rocks. ** The deficit appears due to high content of arsenopyrite mineralization, the samples were assayed for As with ICP-MS, see Table 5. VP-10, AK-706-granite porphyry; AK-710, AK-712, AK-900K, AK-900C, AK-900T—quartz-albite-muscovite metasomatite; AK-707—quartz-arsenopyrite-tourmaline metasomatite; AK-711—quartz metasomatite. n.a. $=$ not assayed. 
Table 5. ICP-MS data for granite porphyry and altered rocks of the Oleninskoe deposit, $\mathrm{g} / \mathrm{t}$.

\begin{tabular}{|c|c|c|c|c|c|c|}
\hline Sample \# & AK-706 & ВП-43 & AK-707 & AK-710 & AK-712 & AK-711 \\
\hline $\mathrm{Li}$ & 174 & 16 & 18 & 107 & 103 & 19 \\
\hline $\mathrm{Be}$ & 0.89 & 0.67 & 0.13 & 0.44 & 0.64 & 0.09 \\
\hline Sc & 1.88 & 2.42 & 7.76 & 34 & 29 & 3.99 \\
\hline V & 25 & 22 & 59 & 247 & 296 & 11 \\
\hline $\mathrm{Cr}$ & 281 & 400 & 34 & 219 & 166 & 917 \\
\hline Co & 5.16 & 4.50 & 29 & 9.78 & 31 & 5.76 \\
\hline $\mathrm{Ni}$ & 29 & 18 & 69 & 12 & 29 & 67 \\
\hline $\mathrm{Cu}$ & 12 & 19 & 270 & 207 & 400 & 78 \\
\hline $\mathrm{Zn}$ & 20 & 110 & 91 & 47 & 63 & 204 \\
\hline $\mathrm{Ga}$ & 24 & 19 & 3.49 & 15 & 15 & 1.47 \\
\hline As & 29 & n.a. & 67792 & 41304 & 18825 & 1385 \\
\hline Se & n.a. & n.a. & 2.30 & $<1.00$ & n.a. & n.a. \\
\hline $\mathrm{Rb}$ & 48 & 56 & 18 & 95 & 35 & 3.46 \\
\hline $\mathrm{Sr}$ & 151 & 117 & 25 & 57 & 67 & 6.74 \\
\hline $\mathrm{Y}$ & 3.22 & 14 & 1.40 & 1.20 & 0.82 & 0.48 \\
\hline $\mathrm{Zr}$ & 101 & 127 & 6.79 & 12 & 15 & 2.25 \\
\hline $\mathrm{Nb}$ & 1.46 & 6.64 & 0.33 & 0.73 & 0.85 & 0.13 \\
\hline Mo & 1.29 & 2.30 & 0.52 & 0.44 & 0.47 & 4.84 \\
\hline $\mathrm{Ag}$ & 1.05 & 0.49 & 228 & 15 & 149 & 145 \\
\hline $\mathrm{Cd}$ & 0.11 & n.a. & 1.03 & 0.16 & 0.49 & 1.76 \\
\hline Sn & 0.57 & 1.08 & 0.55 & 1.07 & 1.02 & 0.90 \\
\hline $\mathrm{Sb}$ & 2.11 & 0.30 & 717 & 60 & 48 & 5.28 \\
\hline $\mathrm{Te}$ & n.a. & n.a. & 1.04 & 1.48 & 0.19 & 2.67 \\
\hline Cs & 9.73 & 13 & 5.76 & 8.85 & 5.16 & 1.34 \\
\hline $\mathrm{Ba}$ & 187 & 395 & 42 & 154 & 79 & 5.80 \\
\hline $\mathrm{La}$ & 9.00 & 36 & 1.01 & 1.34 & 0.69 & 0.34 \\
\hline $\mathrm{Ce}$ & 14 & 75 & 2.01 & 3.41 & 1.89 & 0.76 \\
\hline $\operatorname{Pr}$ & 1.81 & 8.93 & 0.26 & 0.55 & 0.39 & 0.09 \\
\hline $\mathrm{Nd}$ & 6.24 & 33 & 1.18 & 2.73 & 2.06 & 0.43 \\
\hline $\mathrm{Sm}$ & 1.12 & 6.47 & 0.28 & 0.67 & 0.63 & 0.10 \\
\hline $\mathrm{Eu}$ & 0.35 & 1.65 & 0.09 & 0.17 & 0.18 & 0.03 \\
\hline $\mathrm{Gd}$ & 1.05 & 4.47 & 0.23 & 0.48 & 0.45 & 0.07 \\
\hline $\mathrm{Tb}$ & 0.10 & 0.53 & 0.04 & 0.05 & 0.05 & 0.01 \\
\hline Dy & 0.54 & 3.07 & 0.25 & 0.24 & 0.25 & 0.07 \\
\hline Ho & 0.10 & 0.56 & 0.05 & 0.05 & 0.05 & 0.02 \\
\hline $\mathrm{Er}$ & 0.29 & 1.55 & 0.16 & 0.14 & 0.15 & 0.06 \\
\hline $\mathrm{Tm}$ & 0.04 & 0.22 & 0.02 & 0.02 & 0.02 & 0.01 \\
\hline $\mathrm{Yb}$ & 0.26 & 1.55 & 0.19 & 0.15 & 0.15 & 0.05 \\
\hline $\mathrm{Lu}$ & 0.04 & 0.24 & 0.02 & 0.03 & 0.02 & 0.01 \\
\hline $\mathrm{Hf}$ & 1.96 & 3.90 & 0.18 & 0.41 & 0.48 & 0.07 \\
\hline $\mathrm{Ta}$ & 0.16 & 0.54 & 0.02 & 0.07 & 0.06 & n.a. \\
\hline W & 3.34 & n.a. & 3.75 & 15.64 & 20.51 & 4.06 \\
\hline $\mathrm{Tl}$ & 0.24 & 0.80 & 4.77 & 0.47 & 0.38 & 0.03 \\
\hline $\mathrm{Pb}$ & 9.66 & 88 & 2238 & 133 & 137 & 20 \\
\hline $\mathrm{Bi}$ & n.a. & n.a. & 1.91 & 0.12 & 0.16 & 0.05 \\
\hline Th & 3.42 & 9.44 & 0.08 & 0.17 & 0.16 & 0.06 \\
\hline $\mathrm{U}$ & 0.89 & 2.95 & 0.07 & 0.07 & 0.10 & 0.08 \\
\hline
\end{tabular}

n.a. = not assayed.

The geochemical association of the metals in the mineralized altered rocks includes $\mathrm{Au}-\mathrm{As}-\mathrm{Ag}-\mathrm{Sb}-\mathrm{Cu}-\mathrm{Pb}-\mathrm{W}$ (Table 5). The concentration coefficient of $\mathrm{As}, \mathrm{Ag}$, and $\mathrm{Sb}$ in the mineralized rocks is more than 100 if compared to the unaltered granite porphyry (Figure 13). The highest content of $\mathrm{As}, \mathrm{Ag}, \mathrm{Pb}$, and $\mathrm{Sb}$ was found in quartz-arsenopyritetourmaline rock (Figure 13, Table 5). Quartz metasomatic rock is not as rich in $\mathrm{Pb}, \mathrm{Ag}$, and $\mathrm{Sb}$ as quartz-albite-muscovite and quartz-arsenopyrite-tourmaline metasomatites (Table 5), but it is rich in $\mathrm{Au}$ (Table 4). The Au/Ag ratio in the mineralized rocks is <0.2 [29], except the quartz metasomatite. 

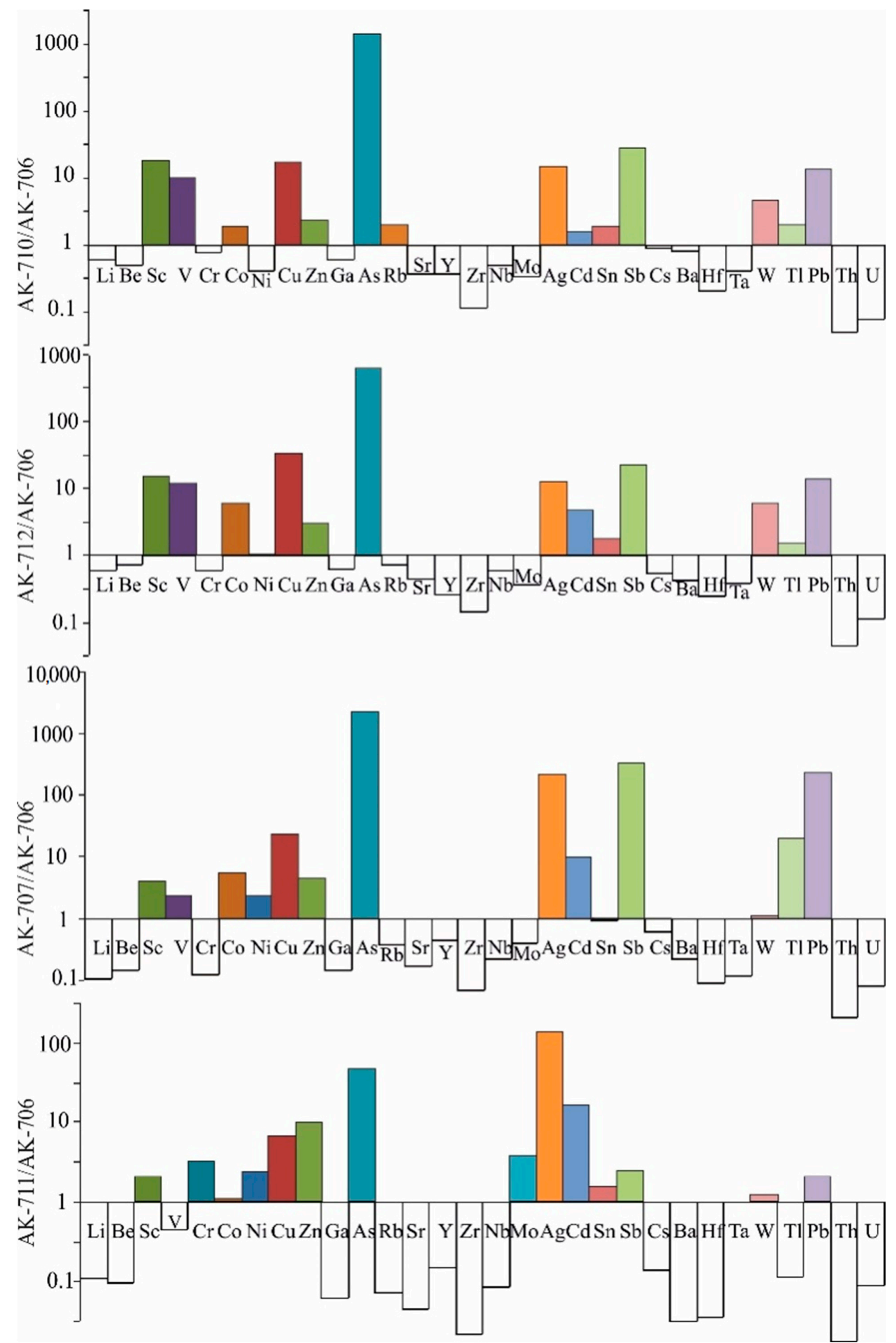

Figure 13. Trace elements spectra of quartz-albite-muscovite (AK-710 and AK-712), quartz-arsenopyrite-tourmaline (AK-707), and quartz (AK-711) metasomatic rocks from lens 2, compared to granite porphyry (AK-706). 
The geochemical characteristics of the rocks correspond well to the composition of mineralization (Table 6). Arsenopyrite, pyrrhotite, and ilmenite are the most abundant ore minerals, which are present in all altered rocks [37,38]. Sporadic ore minerals in biotitizated and diopsidizated amphibolite are chalcopyrite and sphalerite; pentlandite and electrum are rare. Quartz-arsenopyrite-tourmaline and quartz metasomatic rocks in the exocontact zones of granite porphyry contain rich $\mathrm{Pb}-\mathrm{Ag}-\mathrm{Sb}-\mathrm{Au}$ mineralization totaling more than 50 mineral phases: 20 of them are the minerals of the precious metals Ag and $\mathrm{Au}$ (Tables 6 and 7). Ilmenite in quartz-arsenopyrite-tourmaline and quartz metasomatic rocks is partly (in the outer parts of the grains) or fully replaced by rutile $[37,38]$.

Four types of minerals of the Au-Ag series were recognized in the deposit: 1 -electrum 25-32 mas.\% Au in association with arsenopyrite, löllingite, and pyrrhotite; 2-electrum 33-47 mas.\% Au in intergrowths with galena, dyscrasite, and sulfosalts; 3-gold (78-95 mas.\% $\mathrm{Au})$ in quartz; 4 - native silver ( $<7$ mas. \% Au) in the crust of weathering of the ore [37]. Types 1 and 3 are widespread in the deposit, and 2 and 4 relate only to the quartz-arsenopyritetourmaline rocks rich in $\mathrm{Pb}-\mathrm{Ag}$-Sb. Mustard gold was found in the oxidized ore with high $\mathrm{Ag-Sb}$ electrum. These mineral aggregates consist of electrum, Fe and Sb oxides, Ag chlorides, and bromides [38].

In the Oleninskoe ores we see fine intergrowths of $\mathrm{Ag}, \mathrm{Cd}, \mathrm{Pb}, \mathrm{As}, \mathrm{Sb}$ and $\mathrm{Te}$ minerals. These multiphase aggregates are up to $0.2 \mathrm{~mm}$ in size, and the size of individual micrograins in the intergrowths is $<5 \mu \mathrm{m}$. The polymineral intergrowths adjoin bigger grains of argentotetrahedrite, pyrrhotite, and galena host sulfides (Figures 14 and 15).
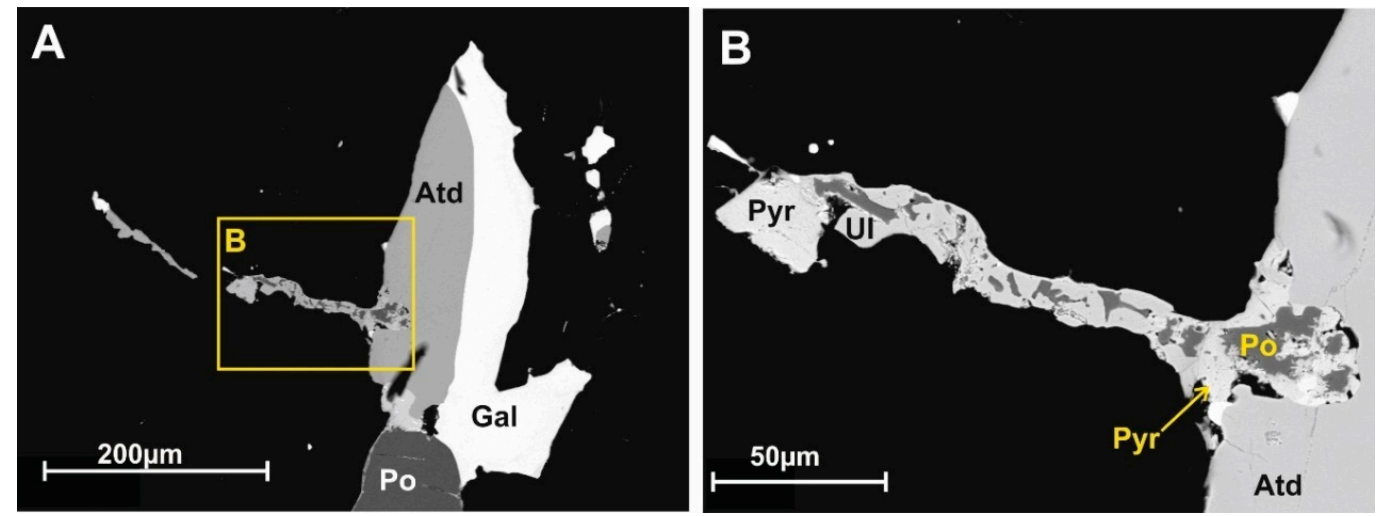

Figure 14. Aggregate of ulmannite (Ul), pyrrhotite (Po), and pyrargyrite (Pyr) at the boundary of argentotetrahedrite (Atd) grain: (A) general view, (B) detailed area. Back scattered electron images (BEI).
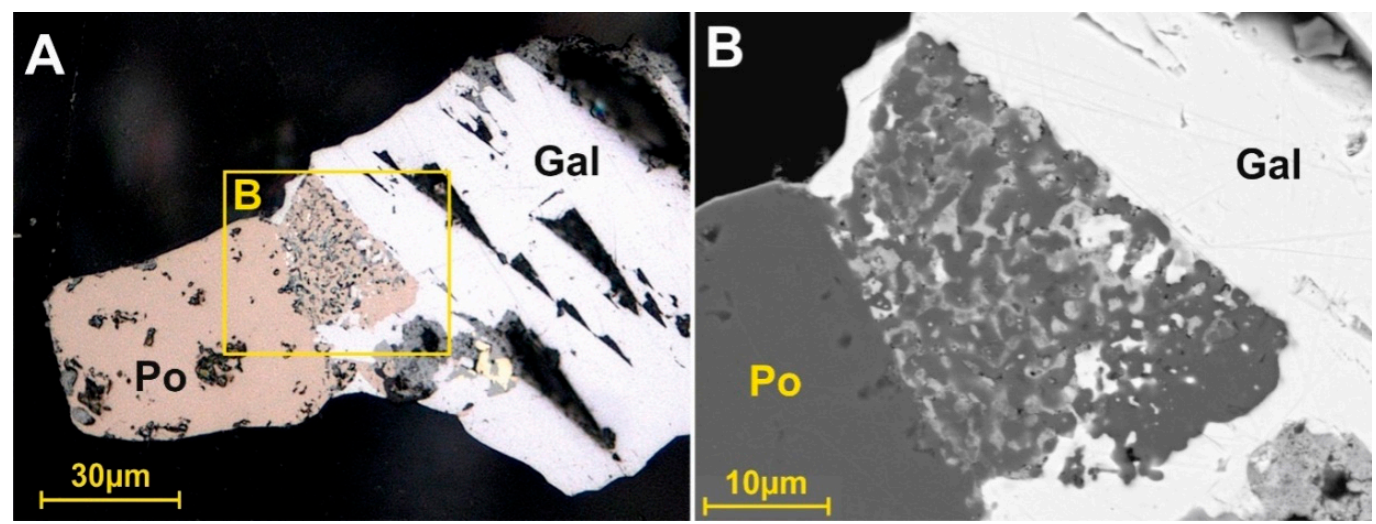

Figure 15. (A) aggregate of pyrrhotite (Po), galena (Gal), argentotetrahedrite (gray), and chalcopyrite (yellow) in galena, polished section photo under plane polarized light; (B) BEI of the aggregate. 
Table 6. Ore minerals (native metals, sulfides, and their analogues) in the rocks of the Oleninskoe deposit.

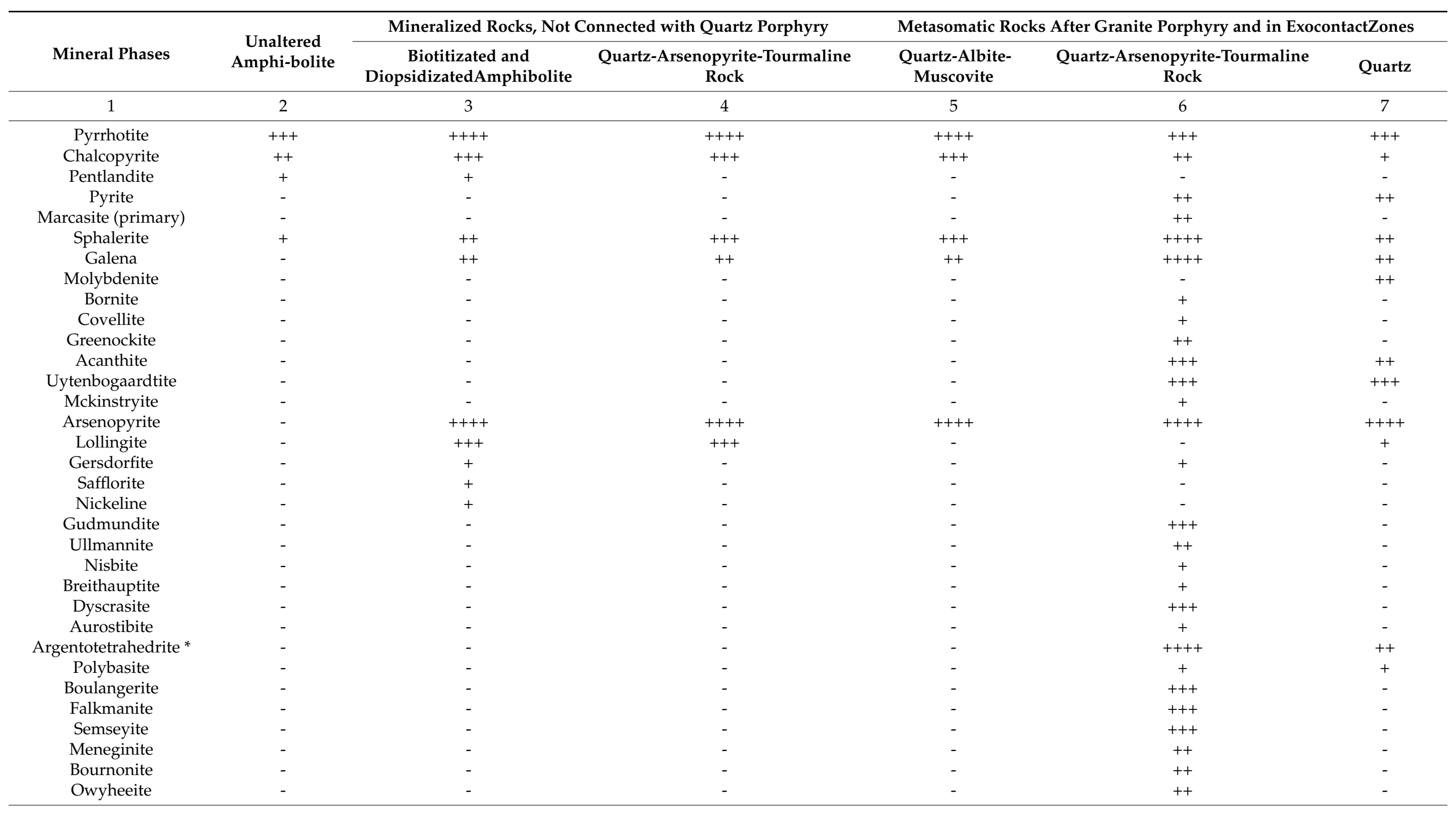


Table 6. Cont.

\begin{tabular}{|c|c|c|c|c|c|c|}
\hline \multirow[b]{2}{*}{ Mineral Phases } & \multirow{2}{*}{$\begin{array}{c}\text { Unaltered } \\
\text { Amphi-bolite }\end{array}$} & \multicolumn{2}{|c|}{ Mineralized Rocks, Not Connected with Quartz Porphyry } & \multicolumn{3}{|c|}{ Metasomatic Rocks After Granite Porphyry and in ExocontactZones } \\
\hline & & $\begin{array}{c}\text { Biotitizated and } \\
\text { DiopsidizatedAmphibolite }\end{array}$ & $\begin{array}{c}\text { Quartz-Arsenopyrite-Tourmaline } \\
\text { Rock }\end{array}$ & $\begin{array}{l}\text { Quartz-Albite- } \\
\text { Muscovite }\end{array}$ & $\begin{array}{c}\text { Quartz-Arsenopyrite-Tourmaline } \\
\text { Rock }\end{array}$ & Quartz \\
\hline 1 & 2 & 3 & 4 & 5 & 6 & 7 \\
\hline Diaphorite & - & - & - & - & +++ & - \\
\hline Ramdohrite & - & - & - & - & ++ & - \\
\hline Uchucchacuaite & - & - & - & - & ++ & - \\
\hline Fizelyite & - & - & - & - & ++ & - \\
\hline Stephanite & - & - & - & - & ++ & - \\
\hline Miargyrite & - & - & - & - & + & - \\
\hline Billingsleyite & - & - & - & - & + & - \\
\hline Dervillite & - & - & - & - & + & - \\
\hline Proustite & - & - & - & - & + & - \\
\hline Hessite & - & - & - & - & ++ & ++ \\
\hline Stutzite & - & - & - & - & + & - \\
\hline Cervelleite & - & - & - & - & + & - \\
\hline Calaverite & - & - & - & - & + & - \\
\hline Native Bismuth & - & - & - & - & + & - \\
\hline Native Gold & - & ++ & ++ & ++ & +++ & +++ \\
\hline Native Arsenic & - & - & - & - & + & - \\
\hline
\end{tabular}

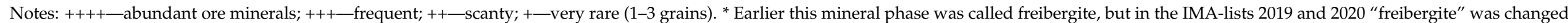
to "argentotetrahedrite". 
Table 7. Electron microprobe data in wt.\% for selected $\mathrm{Ag}, \mathrm{Pb}$, and $\mathrm{Sb}$ mineral phases from the Oleninskoe deposit.

\begin{tabular}{|c|c|c|c|c|c|c|c|c|c|c|c|c|c|c|}
\hline Mineral & Dyscrasite & Dyscrasite & Argentotetrahedrite & Argentotetrahedrite & Argentotetrahedrite & Bournonite & Meneghinite & Owyheeite & Diaphorite & Uchucchacuaite & Fyzeliite & Pyrargyrite & Uytenbogaardtite & Hessite \\
\hline $\mathrm{S}$ & 0.03 & bdl & 21.92 & 20.19 & 20.37 & 19.02 & 16.50 & 18.52 & 19.23 & 20.32 & 21.39 & 17.84 & 11.15 & 0.04 \\
\hline $\mathrm{Mn}$ & n.a. & n.a. & n.a. & bdl & n.a. & 0.03 & bdl & bdl & n.a. & 2.70 & 0.58 & n.a. & n.a. & n.a. \\
\hline $\mathrm{Fe}$ & bdl & 0.01 & 5.34 & 5.14 & 5.18 & 0.06 & 0.07 & 0.04 & n.a. & 0.46 & 0.83 & bdl & 0.15 & bdl \\
\hline Co & n.a. & n.a. & 0.01 & bdl & bdl & n.a. & n.a. & n.a. & n.a. & bdl & n.a. & n.a. & bdl & n.a. \\
\hline $\mathrm{Ni}$ & n.a. & bdl & bdl & bdl & 0.01 & bdl & bdl & bdl & n.a. & bdl & n.a. & n.a. & bdl & bdl \\
\hline $\mathrm{Cu}$ & 0.01 & 0.02 & 22.01 & 16.02 & 15.00 & 12.49 & 1.46 & bdl & n.a. & 0.07 & n.a. & bdl & n.a. & bdl \\
\hline $\mathrm{Zn}$ & n.a. & 0.01 & 0.78 & 0.69 & 0.61 & n.a. & n.a. & bdl & n.a. & bdl & n.a. & n.a. & n.a. & n.a. \\
\hline As & bdl & bdl & bdl & 0.28 & 0.22 & bdl & bdl & bdl & n.a. & bdl & n.a. & bdl & bdl & 0.15 \\
\hline Se & n.a. & n.a. & bdl & bdl & bdl & n.a. & n.a. & bdl & n.a. & n.a. & n.a. & 0.02 & n.a. & n.a. \\
\hline $\mathrm{Ag}$ & 72.61 & 69.84 & 22.47 & 30.38 & 31.92 & n.a. & 0.18 & 4.74 & 24.01 & 6.16 & 9.05 & 58.68 & 59.86 & 62.00 \\
\hline Cd & n.a. & n.a. & n.a. & 0.27 & n.a. & bdl & bdl & n.a. & n.a. & bdl & 1.50 & bdl & n.a. & n.a. \\
\hline $\mathrm{Sb}$ & 24.03 & 19.00 & 26.72 & 26.66 & 26.06 & 24.41 & 17.78 & 26.20 & 25.73 & 34.21 & 33.96 & 22.28 & n.a. & 0.24 \\
\hline $\mathrm{Te}$ & n.a. & n.a. & bdl & n.a. & bdl & n.a. & n.a. & bdl & n.a. & n.a. & n.a. & n.a. & n.a. & 37.52 \\
\hline $\mathrm{Au}$ & 2.29 & 10.46 & bdl & n.a. & bdl & n.a. & n.a. & n.a. & n.a. & n.a. & n.a. & bdl & 26.88 & 0.35 \\
\hline $\mathrm{Pb}$ & bdl & 0.07 & 0.33 & bdl & 0.73 & 42.73 & 64.27 & $\mathrm{bdl}$ & n.a. & n.a. & n.a. & n.a. & n.a. & n.a. \\
\hline $\mathrm{Bi}$ & n.a. & n.a. & 0.03 & n.a. & 0.11 & n.a. & $\begin{array}{l}\text { n.a. } \\
\text { n. }\end{array}$ & 50.18 & 31.22 & 34.52 & 32.71 & 0.18 & n.a. & $\begin{array}{l}\text { n.a. } \\
\text { n.a. }\end{array}$ \\
\hline Total & 98.96 & 99.41 & 99.60 & 99.63 & 100.20 & 98.74 & 100.26 & 99.68 & 100.19 & 98.44 & 100.03 & 99.00 & 98.04 & 100.28 \\
\hline \multicolumn{15}{|c|}{ Formulae coefficients in $\mathrm{Ag}, \mathrm{Pb}$, and $\mathrm{Sb}$ mineral phases. } \\
\hline $\mathrm{s}$ & 0.005 & 0.001 & 13.000 & 13.000 & 13.000 & 3.000 & 24.000 & 28.000 & 8.000 & 12.000 & 24.000 & 2.998 & 2.000 & 0.004 \\
\hline Mn & - & - & - & 0.000 & - & 0.002 & 0.000 & 0.000 & - & 0.931 & 0.378 & - & - & - \\
\hline $\mathrm{Fe}$ & 0.000 & 0.001 & 1.819 & 1.901 & 1.897 & 0.005 & 0.056 & 0.035 & - & 0.156 & 0.536 & 0.000 & 0.016 & 0.000 \\
\hline Co & - & - & 0.004 & 0.000 & 0.000 & - & - & - & - & 0.000 & - & - & 0.000 & - \\
\hline $\mathrm{Ni}$ & - & 0.000 & 0.000 & 0.000 & 0.002 & 0.000 & 0.000 & 0.000 & - & 0.000 & - & - & 0.000 & 0.000 \\
\hline $\mathrm{Cu}$ & 0.001 & 0.002 & 6.588 & 5.207 & 4.833 & 0.994 & 1.074 & 0.000 & - & 0.020 & - & 0.000 & - & 0.000 \\
\hline $\mathrm{Zn}$ & & 0.001 & 0.226 & 0.219 & 0.191 & - & - & 0.000 & - & 0.000 & - & - & - & - \\
\hline As & 0.000 & 0.000 & 0.000 & 0.077 & 0.060 & 0.000 & 0.000 & 0.000 & - & 0.000 & - & 0.000 & 0.000 & 0.007 \\
\hline $\mathrm{Se}$ & & - & 0.000 & - & - & - & - & 0.000 & - & - & - & 0.002 & - & \\
\hline $\mathrm{Ag}$ & 3.394 & 4.144 & 3.961 & 5.817 & 6.057 & - & 0.078 & 2.130 & 2.970 & 1.080 & 3.020 & 2.932 & 3.191 & 1.923 \\
\hline $\mathrm{Cd}$ & & - & - & 0.049 & - & 0.000 & 0.000 & & & 0.000 & 0.826 & 0.000 & - & \\
\hline $\mathrm{Sb}$ & 0.995 & 0.999 & 4.174 & 4.521 & 4.381 & 1.014 & 6.809 & 10.430 & 2.819 & 5.319 & 10.034 & 0.986 & - & 0.006 \\
\hline $\mathrm{Te}$ & - & - & 0.000 & - & - & - & - & 0.000 & - & - & - & - & - & 0.984 \\
\hline $\mathrm{Au}$ & 0.059 & 0.340 & 0.000 & - & 0.000 & - & - & - & - & - & - & 0.000 & 0.785 & 0.006 \\
\hline $\mathrm{Pb}$ & 0.000 & 0.000 & 0.030 & 0.000 & 0.072 & 1.043 & 14.464 & 0.000 & - & - & - & - & - & - \\
\hline $\mathrm{Bi}$ & - & - & 0.003 & - & 0.010 & - & - & 11.741 & 2.010 & 3.154 & 5.678 & 0.005 & - & - \\
\hline
\end{tabular}

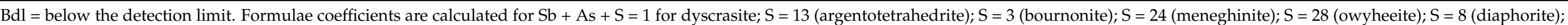

$\mathrm{S}=12$ (uchucchacuaite); $\mathrm{S}=24$ (fyzeliite) $\mathrm{S}+\mathrm{Se}=3$ (pyrargyrite); $\mathrm{S}=2$ (uytenbogaardtite); $\mathrm{Te}+\mathrm{S}+\mathrm{As}+\mathrm{Sb}=2$ (hessite). n.a. $=$ not assayed. 
We interpret the origin of these multiphase grains as a product of sulfide melt crystallization [40]. It is known that in the case of temperature increases, partial melting of sulfides begins when the whole rock is solid, before the melting of silicate phases ("sulfide anatexis"). A low melting temperature is characteristic of $\mathrm{Zn}, \mathrm{Ga}, \mathrm{Ag}, \mathrm{Cd}, \mathrm{In}, \mathrm{Hg}, \mathrm{Tl}, \mathrm{Pb}$, $\mathrm{As}, \mathrm{Sb}, \mathrm{Bi}, \mathrm{Se}$, and Te sulfides, and the first melt appears in the systems $\mathrm{Ag}-\mathrm{Pb}-\mathrm{S}, \mathrm{Pb}-\mathrm{Sb}-\mathrm{S}$, $\mathrm{Ag}-\mathrm{Sb}-\mathrm{S}, \mathrm{PbS}-\mathrm{CuS}-\mathrm{Sb}_{2} \mathrm{~S}_{3}$ and other triple and pseudotriple systems in the temperature interval $300-500{ }^{\circ} \mathrm{C}$ [39]. In the case of metamorphism under conditions of amphibolitegranulite facies $\left(\mathrm{T}=500-800^{\circ} \mathrm{C}\right)$, partial melting of low-melting-point sulfides begins in the rocks, and later, when the temperature decreases, the sulfide melt crystallizes and forms multiphase intergrowths of sulfides, sulfosalts, tellurides, and selenides. These structures of sulfide melt crystallization were described in the ores of many polymetal and gold deposits in metamorphic complexes, for example, Broken Hill (Australia) [39], Montauban [41] and Hemlo (Canada) [42,43], and Bleikvassli (Norway) [44].

The following mineral associations were found in the multiphase intergrowths in the Oleninskoe deposit [45]: galena + argentotetrahedrite \pm pyrrhotite (PbS-CuS- $\mathrm{Ag}_{2} \mathrm{~S}-\mathrm{FeS}-$ $\mathrm{Sb}_{2} \mathrm{~S}_{3}$ system); pyrrhotite + pyrargyrite $\left(\mathrm{FeS}-\mathrm{Ag}_{2} \mathrm{~S}-\mathrm{Sb}_{2} \mathrm{~S}_{3}\right)$; galena + ullmannite + argentotetrahedrite (PbS-NiS-CuS-Sb $\left.{ }_{2} \mathrm{~S}_{3}\right)$; diaphorite + pyrargyrite + galena $\left(\mathrm{PbS}-\mathrm{Ag}_{2} \mathrm{~S}-\mathrm{Sb}_{2} \mathrm{~S}_{3}\right)$; galena + fyzeliite (or uchucchacuaite) (PbS- $\left.\mathrm{Ag}_{2} \mathrm{~S}_{-} \mathrm{Sb}_{2} \mathrm{~S}_{3}\right)$; intergrowths of argentotetrahedrites with different $\mathrm{Ag}$ and $\mathrm{Cu}$ content $\left(\mathrm{CuS}-\mathrm{Ag}_{2} \mathrm{~S}-\mathrm{Sb}_{2} \mathrm{~S}_{3}\right)$.

The rocks of the Oleninskoe Au-Ag deposit were metamorphosed under conditions of lower amphibolite facies at $500-600{ }^{\circ} \mathrm{C}$ [26]. This temperature was high enough to start melting $\mathrm{Pb}, \mathrm{Ag}, \mathrm{Cu}$, and $\mathrm{Sb}$ sulfides. The signs indicating the origin of the multiphase aggregates as a product of crystallization of sulfide melt are the following: multiphase composition of the grains, where minerals of the low-melting-point metals $\mathrm{Pb}, \mathrm{Ag}, \mathrm{Sb}$, and Te are necessarily present; absence of signs of replacement of the earlier formed minerals by the later ones; drop-like or roundish irregular forms of the aggregates, which adjoin a larger grain of host sulfide; multiphase sulfide filling of fractures in quartz rock mass. These points fully correspond to the signs of sulfide melt crystallization in sulfide ores as they are given in [39].

\subsection{Fluid Composition}

Total salinity of fluid in the inclusions in quartz from the studied deposits varies from medium to high (Table 8) [46]. Quartz from the Pellapahk mineralized rocks shows high salinity of fluid inclusions of $341 \mathrm{~g} / \mathrm{kg} \mathrm{H}_{2} \mathrm{O}$ (Table 8). In the Oleninskoe deposit, total salinity varies, depending on the metasomatic rocks: in quartz-albite-muscovite and quartz metasomatites it is moderate at $\sim 130 \mathrm{~g} / \mathrm{kg} \mathrm{H}_{2} \mathrm{O}$, and in quartz-arsenopyrite-tourmaline rock it is even more than $400 \mathrm{~g} / \mathrm{kg} \mathrm{H}_{2} \mathrm{O}$. The latter corresponds well to the data obtained earlier for the same rocks [47].

Table 8. Concentration of the main components in fluids from the Oleninskoe and Pellapahk deposits, $\mathrm{g} / \mathrm{kg} \mathrm{H}{ }_{2} \mathrm{O}$ [46].

\begin{tabular}{ccccc}
\hline Deposit & & Oleninskoe & Pellapahk \\
\hline Sample \# & AK-707 & AK-710A & AK-711 & AK-721 \\
\hline $\mathrm{Cl}^{-}$ & 131.8 & 64.5 & 47.7 & 52.6 \\
$\mathrm{SO}_{4}^{2-}$ & 134.2 & 9.85 & 40.1 & 137.8 \\
$\mathrm{HCO}_{3}-$ & 0.55 & 2.42 & 0.00 & 32.84 \\
$\mathrm{~F}^{-}$ & 0.00 & 0.00 & 10.1 & 0.00 \\
$\mathrm{Na}^{+}$ & 47.0 & 15.9 & 0.49 & 62.1 \\
$\mathrm{~K}^{+}$ & 31.5 & 6.96 & 34.8 & 36.3 \\
$\mathrm{Ca}^{2+}$ & 61.8 & 21.1 & 0.30 & 10.6 \\
$\mathrm{Mg}^{2+}$ & 7.60 & 1.99 & 134.6 & 9.00 \\
Total salinity & 414.4 & 122.7 & 282.6 & 341.2 \\
$\mathrm{CO}_{2}$ & 416.7 & 625.0 & 0.76 & 206.6 \\
$\mathrm{CH}_{4}$ & 2.84 & 0.61 & & 1.74 \\
\hline
\end{tabular}


$\mathrm{Ca}$ and $\mathrm{Na}(\mathrm{Ca}>\mathrm{Na})$ are the two main cations in the fluids in quartz from the Olenickoe gold-silver deposit; potassium and magnesium content is much lower, especially in quartz metasomatic rock. In the Pellapahk Cu-Mo deposit (Table 8), alkaline metals (sodium and potassium) are predominant: together they make up $85 \%$ of mole shares of cations in the inclusions in quartz.

The anion composition of the fluids is also different. In the Oleninskoe deposit, it is characterized by a prevalence of $\mathrm{Cl}^{-}$over $\mathrm{SO}_{4}{ }^{2-}$ (in mole shares). The mole share of $\mathrm{Cl}$ reaches $95 \%$ in quartz-albite-muscovite rock. $\mathrm{HCO}_{3}{ }^{-}$content is low. In the Pellapahk deposit, the mole share of $\mathrm{Cl}^{-}$is relatively low: $43 \%$ of the anions, close to the one of $\mathrm{SO}_{4}{ }^{2-}(41 \%) ; \mathrm{HCO}_{3}{ }^{-}$accounts for $15 \%$.

The $\mathrm{Na} / \mathrm{Cl}$ ratio in the inclusions varies from 0.33 to 0.55 in quartz from the Oleninskoe deposit. This indicates a significant role of $\mathrm{Ca}$ and $\mathrm{Mg}$ chlorides in the fluids. The $(\mathrm{Na}+\mathrm{K}) / \mathrm{Cl}$ ratio in quartz from the Pellapahk deposit is 1.97. This means that sodium and potassium sulfates and carbonates are present in the fluid inclusions.

\section{Discussion}

The fact that the intrusions, which host the Pellapahk and the Oleninskoe deposits, refer to one and the same intrusive complex, can be proved by the age of the rocks and by their geochemical characteristics.

The age of the Pellapahk intrusion is $2828 \pm 8 \mathrm{Ma}$, and the age of the Oleninskoe granite porphyry sills is $2817 \pm 9 \mathrm{Ma}$; the values match within the error limits. The difference between the older and the younger ages does not exceed the typical duration of porphyry systems development (10-20 Ma) defined in the Phanerozoic belts [2].

Chemical composition of the unaltered rocks from the deposits does not differ significantly: all of them belong to the calc-alkaline series of metaluminous granites with moderate alkalinity, and the fields of rock composition overlap in the classification diagrams (Figure 5).

The REE spectra of granite porphyry from the studied deposits are of the same form, characterized by enrichment in light REE and the absence of the Eu anomaly (Figure 6). This form of spectrum is typical for I-granites formed in zones of subduction and island arcs [34], and differs significantly from the REE spectra of tourmaline plagiomicrocline anorogenic granites from the intrusions located north of the Pellapahk (Figure 1) [48].

In the Phanerozoic belts, the porphyry intrusions form at a depth of 1-6 km and produce magmatic porphyry-epithermal ore systems, which occur in near-surface conditions. These systems show a specific vertical and lateral zoning in rock alteration and in the distribution of the mineralization, from deep to shallow horizons (and from the center to the edge) $(\mathrm{Mo}, \mathrm{Cu})-(\mathrm{Cu})-(\mathrm{Pb}, \mathrm{Zn})-(\mathrm{Au}, \mathrm{Ag}, \mathrm{As}, \mathrm{Sb})$; the zoning can be full or fragmentary $[2,40,49,50]$. Similar systems formed in the Precambrian, or even in the Archean, but the probability they were preserved and have not been eroded since that time is low.

If we consider the Pellapahk and the Oleninskoe deposits as parts of an Archean porphyry-epithermal system, then the Pellapahk Cu-Mo deposit is located at its centre, and the Oleninskoe $(\mathrm{Au}, \mathrm{Ag}, \mathrm{As}, \mathrm{Sb})$ is a distal epithermal deposit in relation to the Pellapahk deposit.

Porphyry $\mathrm{Cu}$ deposits in the Phanerozoic are known to display a consistent, broadscale alteration zoning that comprises, centrally from the bottom upward, zones of sodiccalcic, potassic, chlorite-sericite, sericitic, and advanced argillic (quartz-pyrophyllite, quartz-alunite, quartz-kaolinite) alteration [2,4]. In the Pellapahk deposit, we see zones of quartz-microcline (potassic alteration), quartz-muscovite (sericitic zone), and quartzandalusite-muscovite (advanced argillic zone) metasomatic rocks (Figures 2 and 3). This zoning generally corresponds that described for the Phanerozoic deposits, but the altered rocks of the Pellapahk deposit were later metamorphosed: sericite was replaced by muscovite, and alumina silicates of the argillic zone (pyrophyllite, alunite, kaolinite) by andalusite during the Neoarchean metamorphism of lower amphibolite facies. Subsequently, during the Paleoproterozoic metamorphism, kyanite formed paramorphoses after 
andalusite. The origin of the quartz-muscovite-andalusite schists of the Pellapahk deposit as altered and later metamorphosed volcanic rocks was first published by Glagolev [51], who studied petrography of the Kolmozero-Voronya belt in early 1970s when the Cu-Mo mineralization was unknown.

Generally, the Pellapahk granite porphyry was $\mathrm{Si}-\mathrm{K}$ altered, and $\mathrm{Na}, \mathrm{Mg}, \mathrm{Ca}$, and $\mathrm{Fe}$ were partly removed from the rock (Table 1 ). Sodium was taken away from the porphyry system, but $\mathrm{Mg}, \mathrm{Ca}$, and $\mathrm{Fe}$ were re-deposited in the zone of alteration of high-alumina gneiss in the mineral forms of gedrite and cordierite [36].The zone of gedrite-cordierite alteration is $100-150 \mathrm{~m}$ thick and follows the contact with the altered granite porphyry (part of it is shown in Figure 3).

The metamorphism of the mineralized rocks in the Pellapahk deposit can be confirmed by findings of multiphase grains with structures of sulfide melt crystallization, which in the Pellapahk deposit are not as frequent as in the Oleninskoe. Multiphase fine aggregates from the Pellapahk deposit consist of minerals of $\mathrm{Pb}, \mathrm{Ag}, \mathrm{Bi}$, and $\mathrm{Zn}$ galena, argentotetrahedrite, lillianite [45], or minerals of $\mathrm{Cu}, \mathrm{Sb}$, and As tetrahedrite and tennantite, löllingite, and chalcopyrite (Figure 16). It is interesting to note formation of löllingite and the absence of arsenopyrite in the rocks with intense pyrite dissemination.

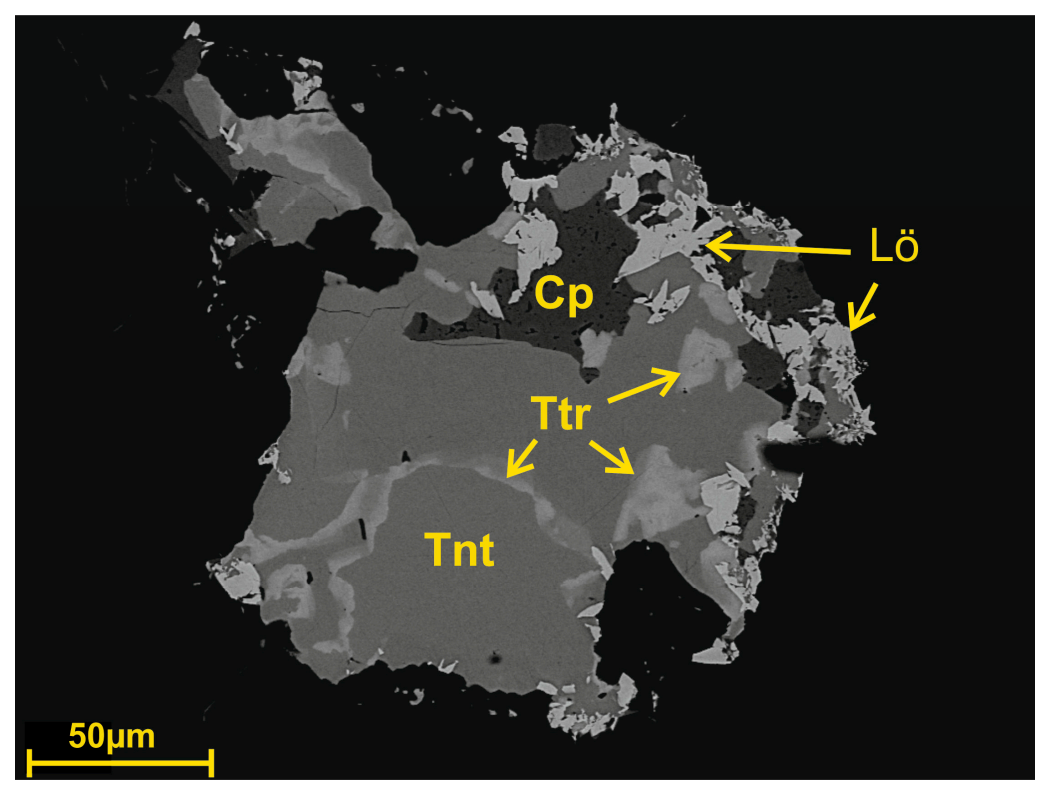

Figure 16. Aggregate of tennantite (Tnt), tetrahedrite (Ttd), chalcopyrite (Cp), and löllingite (Lö) from the Pellapahk deposit. BEI.

Other signs of metamorphism of the ore in the Pellapahk deposit are recrystallization of chalcopyrite with deposition along cleavage in kyanite, which replaces andalusite (Figures 2 and 8), and recrystallization of molybdenite along cleavage in muscovite.

The fact that large amounts of pyrite are preserved within the Pellapahk deposit indicates that high $f\left(\mathrm{~S}_{2}\right)$ conditions must have prevailed during metamorphism.

Alteration processes in the Oleninskoe deposit differ from those in Pellapahk: we see here calcium alteration (diopsidization), potassic alteration (biotitization), and $\mathrm{Si} \pm \mathrm{K}, \mathrm{Na}$ alteration (quartz-albite-muscovite, quartz-arsenopyrite-tourmaline, quartz metasomatites).

The following distinctive features show metamorphism of the mineralized rocks in the Oleninskoe deposit. First, there are numerous findings of multiphase sulfide grains with structures of sulfide melt crystallization [45], described in Section 4.1.2. Then, late metamorphism is indicated by the mineral composition of the altered rocks, where chlorite is absent, calcite is very rare, and actinolite-hornblende and diopside are abundant. Chlorite and carbonates are typical minerals (together with quartz) in altered amphibolite, but 
during amphibolite metamorphism, when $\mathrm{H}_{2} \mathrm{O}$ and $\mathrm{CO}_{2}$ are removed from the rocks, chlorite is replaced by amphiboles [52,53], and the content of carbonates reduces.

Then, pyrite in the Oleninskoe deposit is sporadic, and pyrrhotite is the most abundant sulfide mineral. This can be a result of metamorphism: pyrrhotite replaces pyrite under the conditions of amphibolite metamorphism [53,54].

The composition of the fluid inclusions in quartz varies depending on the character of rock alteration: in the Pellapahk deposit, the fluids are alkaline $(\mathrm{Na}, \mathrm{K})$ and $\mathrm{SO}_{4}{ }^{2-}$ rich, and in the Oleninskoe deposit, they are $\mathrm{Ca}-\mathrm{Mg}-\mathrm{Cl}$ dominant.

Mineralogical and geochemical features of the Oleninskoe deposit indicate its genesis with high oxidizing fluids, which could be generated by a magmatic source [55]. The spatial and genetic relationship of mineralization with the sills of granite porphyry, the geochemical association of metals, an $\mathrm{Au} / \mathrm{Ag}$ ratio of $<0.2$, and the multiplicity of silver mineralization with different $\mathrm{Ag}, \mathrm{Cu}$ and $\mathrm{Pb}$ sulfosalts are all characteristics that enable the classification of the Oleninskoe deposit as a sub-epithermal deposit located in the vicinity of a big granite porphyry intrusion; the Pellapahk intrusion being the most probable. The geological-structural characteristics of the Oleninskoe deposit-its position in a shear zone, the morphology and size of ore bodies, the scale of the deposit, the intensity and zoning of host rocks alteration-do not oppose this model.

If the Oleninskoe and Pellapahk deposits are the parts of the Pellapahk-Oleninskoe porphyry-epithermal system, then the age of primary mineralization is close to the time of the formation of granite porphyry at $2.83-2.81 \mathrm{Ga}$. The deposits were later lower amphibolite metamorphosed together with the hosting volcanic-sedimentary rocks in the Neoarchean $\left(\mathrm{T}=550-600{ }^{\circ} \mathrm{C}, \mathrm{P}=3-4 \mathrm{kBar}\right)$ and in the Paleoproterozoic $\left(\mathrm{T} \sim 530^{\circ} \mathrm{C}\right.$, $\mathrm{P} \sim 5.5 \mathrm{kBar}$ ) [26], and the mineralized rocks demonstrate signs of metamorphism of the ore.

Mineral deposits, associated with granite porphyry intrusions and dykes, are well known in the Fennoscandian and other Precambrian shields around the world. In the Fennoscandian Shield, we can mention the Cu porphyry (with gold) deposit of Aitik in Norbotten, Sweden [56], the molybdenum porphyry deposit ofLobash and neighboring gold deposit Lobash-1 in the Central Karelia [57,58], the minor gold deposits of Taloveis and Falaley in the Kostamuksha greenstone belt, Western Karelia [59], Mo-W with gold occurrences of Yalonvaara and Hatunoya in Southern Karelia [60], etc. The deposits and occurrences in Karelia formed not at the time of crystallization of the porphyry intrusions, but at the stage of the Paleoproterozoic (or rarer, Neoarchean) regional metamorphism [61]. The geological setting, morphology and size of the ore bodies, geochemical characteristics, and mineralogy show these deposits belonging to the orogenic genetic class [62]. In the Kolmozero-Voronya belt, the Nyalm-1 deposit is considered an orogenic gold deposit, associated with a granodiorite porphyry intrusion $[63,64]$.

Some deposits in the Fennoscandian Shield are classified as metamorphosed epithermal: those are the gold deposit of Kutemajarvi in the Tampere belt in South Finland, and the silver (with base metals) deposit of Taivaljarvi in the Tipasjarvi belt in Central Finland.

The Kutemajarvi gold deposit comprises eight tube-like ore bodies, located $500 \mathrm{~m}$ south from the Pukala monzogranite-porhyry tonalite intrusion in the intermediate metavolcanics. The intrusion and the deposit are of the Paleoproterozoic age of 1.90-1.88 Ga [65].

The Taivaljarvi is an Archean stratiform Ag- $\mathrm{Zn}-\mathrm{Pb}$ deposit, consisting of four mineralized horizons formed by fluids of magmatic origin, which migrated along shear zones in felsic pyroclastic rocks (rhyolite tuffs) [66]. The average gold content in the deposit is $0.29 \mathrm{~g} / \mathrm{t}$. The age of the rocks hosting the mineralization is $2.83-2.75 \mathrm{Ga}$ [66].

Thus, the Pellapahk-Oleninskoe porphyry-epithermal system is the oldest system with complex Cu-Mo and Au-Ag mineralization in the Fennoscandian Shield. Distinctive geochemical and mineralogical features distinguish the Oleninskoe deposit from all other gold deposits in Fennoscandia. 


\section{Conclusions}

Gabbro-diorite-granodiorite-granite porphyry intrusions formed at the late stages of the formation of the volcanic-sedimentary sequences of the Kolmozero-Voronya greenstone belt. The age of the intrusions is 2.83-2.82 $\mathrm{Ga}$. $\mathrm{Cu}-\mathrm{Mo}, \mathrm{Au}-\mathrm{Ag}$, and $\mathrm{Au}$ deposits are associated with the quartz porphyry series.

The Pellapahk Cu-Mo and the Oleninskoe Au-Ag deposits are considered two parts of the Pellapahk-Oleninskoe porphyry-epithermal system: the Cu-Mo deposit in a big granite porphyry intrusion makes its central part, and the gold-silver deposit is located in the flank where it is associated with granite porphyry sills.

The following distinctive features indicate the sub-epithermal origin of the $\mathrm{Au}-\mathrm{Ag}$ mineralization in the Oleninskoe deposit: the spatial and genetic relationships with the sills of granite porphyry, the geochemical association of ore elements, an $\mathrm{Au} / \mathrm{Ag}$ ratio of $<0.2$, and the multiplicity of silver mineralization with different $\mathrm{Ag}, \mathrm{Cu}, \mathrm{Pb}$, and $\mathrm{Sb}$ sulfosalts. The geological-structural characteristics of the Oleninskoe deposit (i.e., its location in a shear zone, the morphology and size of ore bodies, the scale of the deposit, the intensity and zoning of host rocks alteration) do not oppose this model.

The Pellapahk-Oleninskoe porphyry-epithermal ore system is probably the oldest one in the Fennoscandian Shield. Mineralized rocks of the Pellapahk and Oleninskoe deposits were later lower amphibolite metamorphosed. An important sign of ore metamorphism is the formation of structures of crystallization of sulfide melt of the low-melting-point metals. In the Oleninskoe ores we see fine intergrowths of $\mathrm{Ag}, \mathrm{Cd}, \mathrm{Pb}, \mathrm{As}, \mathrm{Sb}$, Te minerals galena, argentotetrahedrite, pyrargyrite, pyrrhotite, ullmannite, stutzite, etc. In the Pellapahk CuMo deposit, multiphase fine aggregates consist of $\mathrm{Bi}, \mathrm{Pb}, \mathrm{Sb}$, and As minerals. Other signs of metamorphism of the ore in the Pellapahk deposit are recrystallization of chalcopyrite with re-deposition along cleavage in kyanite, and recrystallization of molybdenite along cleavage in muscovite. Late metamorphism of the ore in the Oleninskoe deposit is indicated by the absence of chlorite and the scarcity of carbonate in altered amphibolite.

Author Contributions: Methodology: A.A.K.; Conceptualization: A.A.K., N.M.K.; Geochronological Study: N.M.K.; Mineralogical Investigations: A.A.K.; Original Draft Writing: A.A.K., N.M.K.; Editing and Review: A.A.K. All authors have read and agreed to the published version of the manuscript.

Funding: The work was carried out under Project 0226-2019-0053 of the Russian Academy of Science.

Institutional Review Board Statement: Not applicable.

Informed Consent Statement: Not applicable.

Data Availability Statement: The data presented in this study are available on request from the corresponding author.

Acknowledgments: The authors thank Vsevolod Prokofiev (IGEM RAS) for study of fluid inclusions composition, Yevgeny Savchenko and Yekaterina Selivanova (GI KSC RAS) for microprobe and X-ray study of minerals, and Alexandr Volkov (IGEM RAS) for helpful discussion of the results. The authors are grateful to the reviewers for their comments, which helped to improve the manuscript.

Conflicts of Interest: The authors declare no conflict of interest.

\section{References}

1. Seedorff, E.; Dilles, J.H.; Proffett, J.M.; Einaudi, M.T.; Zurcher, L.; Stavast, W.J.A.; Johnson, D.A.; Barton, M. Porphyry depositsCharacteristics and origin of hypogene features. Econ. Geol. 2005, 100, 251-298.

2. Sillitoe, R.H. Porphyry-copper systems. Econ. Geol. 2010, 105, 3-41. [CrossRef]

3. Cooke, D.R.; Hollings, P.; Wilkinson, J.J.; Tosdal, R.M. Geochemistry of Porphyry Deposits. In Treatise on Geochemistry, 2nd ed.; Holland, H.D., Turekian, K.K., Eds.; Elsevier: Oxford, UK, 2014; pp. 357-381.

4. Kesler, S.E.; Chryssoulis, S.L.; Simon, G. Gold in porphyry copper deposits: Its distribution and fate. Ore Geol. Rev. 2002, 21, 103-124. [CrossRef]

5. Cooke, D.R.; Simmons, S.F. Characteristics and genesis of epithermal gold deposits. Rev. Econ. Geol. 2000, 13, 221-244.

6. Cooke, D.R.; Hollings, P.; Walshe, J. Giant porphyry deposits-Characteristics, distribution and tectonic controls. Econ. Geol. 2005, 100, 801-818. [CrossRef] 
7. Richards, J.P. Postsubduction porphyry $\mathrm{Cu}-\mathrm{Au}$ and epithermal Au deposits: Products of remelting of subduction-modified lithosphere. Geology 2009, 37, 247-250. [CrossRef]

8. Sillitoe, R.H. Some metallogenic features of gold and copper deposits related to alkaline rocks and consequences for exploration. Miner. Depos. 2002, 37, 4-13. [CrossRef]

9. Kalinin, A.A.; Galkin, N.N. The Precambrian Copper-Molybdenum porphyry deposit Pellapahk (Kolmozero-Voron'ya greenstone belt). Vestnik KNTs RAN 2012, 44, 80-92. (In Russian)

10. Kalinin, A.A.; Kudryashov, N.M.; Galkin, N.N. Occurrences of gold, copper, and molybdenum mineralization in the KolmozeroVoron'ya greenstone belt (Kola Peninsula): Geological characteristics and age. In Gold in the Kola Peninsula and Adjacent Territories; K\&M: Apatity, Russia, 2010; pp. 51-59. (In Russian)

11. Ovoca Gold plc Operational Update 13/09/2007. Available online: http://www.ovocagold.com/upload/20070913_ayax_kola_ \&_goltsovoye_update.pdf (accessed on 2 April 2017).

12. Rozhkov, I.S.; Zhadnova, T.P. On the problem of gold mineralization in the Russian Platform. Doklady AN SSSR 1972, $203,434-437$. (In Russian)

13. Korovkin, V.A.; Turyleva, L.V.; Rudenko, D.G.; Zhuravlev, V.A.; Klyuchnikova, G.N. Underground of the North-West of Russian Federation; VSEGEI: Sankt-Peterburg, Russia, 2003; 754p. (In Russian)

14. Kryazhev, S.G.; Prokofiev, V.Y.; Vasyuta, Y.V. Use of ICP-MS method for assaying of ore-forming fluids. Vestn. Mosc. State Univ. Ser. 4 Geol. 2006, 4, 30-36. (In Russian)

15. Krogh, T.E. A low-contamination method for hydrothermal decomposition of zircon and extraction of $\mathrm{U}$ and $\mathrm{Pb}$ for isotopic age determination. Geochim. Cosmochim. Acta 1973, 37, 485-494. [CrossRef]

16. Ludwig, K.R. PbDat for MS-DOS, Version 1.21; U.S. Geological Survey Open-File Report; U.S. Geological Survey: Reston, VA, USA, 1991; pp. 88-542.

17. Ludwig, K.R. ISOPLOT/Ex. Version 2.06. A Geochronological Toolkit for Microsoft Excel; Berkley Geochronology Center Special Publication: Berkeley, CA, USA, 1999; 49p.

18. Steiger, R.H.; Jager, E. Subcomission of geochronology: Convention of the use of decay constants in geo- and cosmochronology. Earth Planet. Sci. Lett. 1976, 36, 359-362. [CrossRef]

19. Stacey, J.S.; Kramers, I.D. Approximation of terrestrial lead isotope evolution by a two-stage model. Earth Planet. Sci. Lett. 1975, 26, 207-221. [CrossRef]

20. Mints, M.V.; Suleimanov, A.K.; Babayants, P.S. Deep Structure, Evolution, and Minerals in the Early Precabrian Basement of the East European Platform: Interpretation of Materials on Referent Profile 1-EV, Profiles 4 V and TATSEIS; Geokart Geos: Moscow, Russia, 2010; ISBN 978-5-89118-531-9. (In Russian)

21. Nikitin, I.V. Tectonics of the Kolmozero-Voron'ya belt in the light of the conception of horizontal moving. In Regional Tectonics of the Early Precambrian of the USSR; Nauka: Leningrad, Russia, 1980; pp. 104-111. (In Russian)

22. Mints, M.V.; Glaznev, V.N.; Konilov, A.N.; Nikitichev, A.P.; Raevskiy, A.B.; Sedykh, Y.N.; Stupak, V.M.; Fonaryov, V.I. The Early Precambrian of the North-Eastern Part of the Baltic Shield: Paleogeodynamics, Structure and Evolution of the Continental Crust; Nauchny Mir: Moscow, Russia, 1996; 287p. (In Russian)

23. Kudryashov, N.M.; Udoratina, O.V.; Coble, M.A.; Steshenko, E.N.; Gabov, D.A. Age and sources of matter for rare metal pegmatite in the Archean Kolmozero-Voronya greenstone belt: Isotope geochronological study of zircons from muscovite-tourmaline granites. Proc. Fersman Sci. Sess. GIKSC RAS 2018, 15, 222-225. (In Russian) [CrossRef]

24. Kudryashov, N.M.; Lyalina, L.M.; Apanasevich, E.A. Age of rare metal pegmatites from the VasinMyl'k deposit (Kola region): Evidence from of U-Pb geochronology of microlite. Dokl. AN 2015, 461, 321-325. [CrossRef]

25. Astafiev, B.Y.; Viskunova, K.G.; Voinova, O.A.; Glaznev, V.N. State GeologicalMap of Russian Federation. Scale 1:1000000 (the Third Generation). Series Severo-Karsko-Barentsevomorskaya. Sheet $R$-37, 38-Cape Svyatoy Nos, Cape Kanin Nos. Explanatory Note; Cartographic Factory of VSEGEI: Sankt-Peterburg, Russia, 2008; 251p. (In Russian)

26. Drugova, G.M.; Glebovitskiy, V.A.; Duk, V.L.; Kitsul, V.I.; Savel'eva, T.L.; Sedova, I.S.; Semyonov, A.S. High Gradient Regimes of Metamorphism in Development of the Earth crust; Nauka: Leningrad, Russia, 1982; 229p. (In Russian)

27. Daly, J.S.; Balagansky, V.V.; Timmerman, M.J.; Whitehouse, M.J. The Lapland-Kola orogen: Palaeoproterozoic collision and accretion of the northern Fennoscandian lithosphere. Geol. Soc. Lond. Mem. 2006, 32, 579-598. [CrossRef]

28. Kalinin, A.A. Gold in Metamorphic Complexes of the North-Eastern Part of the Fennoscandian Shield; Federal Research Centre 'Kola Science Centre': Apatity, Russia, 2018; 250p. (In Russian)

29. Nikitin, I.V.; Gavrilenko, B.V. Structural and geodynamical diversity of exhumated 'roots' of the Archean interplate suture (Kola Peninsula). In Postcollisional Evolution of Mobile Belts; Institute of Geology and Geochemistry, the Ural Branch of the RAS: Ekaterinburg, Russia, 2001; pp. 126-129. (In Russian)

30. Gavrilenko, B.V.; Nikitin, I.V.; Zozulya, D.R.; Kudryashov, N.M.; Petrovskiy, M.N.; Korsakova, O.P.; Galkin, N.N. Geology, tectonics, age, and metallogeny of the Archean suture zone Kolmozero-Voron'ya. Vestn. Murm. State Tech. Univ. 2002, 5, 43-60. (In Russian)

31. Galkin, N.N. Geology and Mineralogy of Gold Occurrences in the Pellaphk-Oleninsky Ore Unit. Ph.D. Thesis, Kola Science Centre, Apatity, Russia, 2006; 22p. (In Russian).

32. Roizenman, F.M.; Ezhov, S.V.; Ronenson, B.M. Ore-formong metasomatic processes in metamorphic complexes. In Metamorphic Ore Genesis; Kola Science Center: Apatity, Russia, 1980; pp. 77-83. (In Russian) 
33. Frost, B.R.; Barnes, C.G.; Collins, W.J.; Arculus, R.J.; Ellis, D.J.; Frost, C.D. A geochemical classification for granitic rocks. J. Petrol. 2001, 42, 2033-2048. [CrossRef]

34. Turkina, O.M. Lections on Geochemistry of Magmatic and Metamorphic Processes; Novosibirsk State University: Novosibirsk, Russia, 2014; 118p.

35. Sun, S.-S.; McDonough, W.F. Chemical and isotopic systematics of oceanic basalts: Implications for mantle composition and processes. Geol. Soc. Lond. Spec. Publ. 1989, 42, 313-345. [CrossRef]

36. Belolipetskiy, A.P.; Kalinin, A.A.; Petrov, S.I. Mineralogy and Geochemistry of Metasomatites in Deep Fault Zones; Kola Filial of Academy of Science of the USSR: Apatity, Russia, 1987; 115p. (In Russian)

37. Kalinin, A.A.; Kazanov, O.V.; Bezrukov, V.I.; Prokofiev, V.Y. Gold Prospects in the Western Segment of the Russian Arctic: Regional Metallogeny and Distribution of Mineralization. Minerals 2019, 9, 137. [CrossRef]

38. Kalinin, A.A.; Savchenko, Y.E.; Selivanova, E.A. Mustard Gold in the Oleninskoe Gold Deposit, Kolmozero-Voronya Greenstone Belt, Kola Peninsula, Russia. Minerals 2019, 9, 786. [CrossRef]

39. Frost, B.R.; Mavrogenes, J.A.; Tomkins, A.G. Partial melting of sulfide ore deposits during medium- and high-grade metamorphism. Can. Miner. 2002, 40,1-18. [CrossRef]

40. Lang, J.R.; Eastoe, C.J. Relationships between a porphyry Cu-Mo deposit, base and precious metal veins, and Laramide intrusions, Mineral Park, Arizona. Econ. Geol. 1988, 83, 551-567. [CrossRef]

41. Tomkins, A.G. Three mechanisms of ore re-mobilisation during amphibolite facies metamorphism at the Montauban $\mathrm{Zn}-\mathrm{Pb}$ —Au-Ag deposit. Miner. Depos. 2007, 42, 627-637. [CrossRef]

42. Tomkins, A.G.; Frost, B.R.; Pattison, D.R.M. Arsenopyrite melting during metamorphism of sulfide ore deposits. Can. Miner. 2006, 44, 1025-1042. [CrossRef]

43. Tomkins, A.G.; Pattison, D.R.M.; Zaleski, E. The Hemlo gold deposit, Ontario: An example of melting and mobilization of a precious metal-sulfosalt assemblage during amphibolite facies metamorphism and deformation. Econ. Geol. 2004, 99, 1063-1084. [CrossRef]

44. Vokes, F.M. Some aspects of the regional metamorphic mobilization of preexisting sulphide deposits. Miner. Depos. 1971, 6, 122-129. [CrossRef]

45. Kalinin, A.A.; Savchenko, Y.E. Structures of sulfide melt crystallization as an indication of metamorphism of the ores in the Oleninskoe gold deposit. Vestn. MSTU 2020, 23, 29-37. (In Russian) [CrossRef]

46. Kalinin, A.A.; Prokofiev, V.Y. Specific features of genesis of precious and base metals deposits in the Voron'yetundrovsky ore area (Kolmozero-Voronya belt). In Rock and Ore Formation: Achievements and Prospects of Investigations. Proceeding of the 90-th Anniversary of IGEM RAS, Moscow, Russia, 5-9 April 2021; Bortnikov, N.S., Petrov, V.A., Eds.; IGEM RAS: Moscow, Russia, 2020; pp. 128-131. ISBN 978-5-88918-060-9. Available online: http:/ / www.igem.ru/igem_90/ (accessed on 15 January 2021). (In Russian)

47. Volkov, A.V.; Novikov, I.A. The Oleninskoe gold sulfide deposit (Kola peninsula, Russia). Geol. Ore Depos. $2002,44,361-372$.

48. Kudryashov, N.M.; Udoratina, O.V.; Coble, M.A.; Steshenko, E.N. Geochronological and Geochemical Study of Zircon from Tourmaline-Muscovite Granites of the Archaean Kolmozero-Voronya Greenstone Belt: Insights into Sources of the Rare-Metal Pegmatites. Minerals 2020, 10, 760. [CrossRef]

49. Korobeinikov, A.F.; Anan'ev, Y.S.; Gusev, A.I.; Voroshilov, V.G. Ore-Metasomatic and Geochemical Zonation of Gold Fields and Deposits in Folded Belts of Siberia; Tomsk Polytechnical University: Tomsk, Russia, 2013; 458p. (In Russian)

50. Cox, D.P.; Singer, D.A. Mineral Deposit Models. U.S. Geological Survey Bulletin 1693; U.S. Geological Survey: Washington, DC, USA, 1992; 379p.

51. Glagolev, A.A. Influence of the early post-volcanic processes on composition of the metamorphic rocks of the Voron'y Tundry. In Geochemistry, Mineralogy, and Petrology; Book 5; Bolgarian Academy of Sceince: Sofia, Bulgaria, 1976; pp. 108-116. (In Russian)

52. Phillips, G.N.; Powell, R. Formation of gold deposits: A metamorphic devolatilization model. J. Metamorph. Geol. 2010, 28, 689-718. [CrossRef]

53. Gaboury, D. Parameters for the formation of orogenic gold deposits. Appl. Earth Sci. 2019, 128, 124-133. [CrossRef]

54. Phillips, G.N. Metamorphic fluids and gold. Mineral. Mag. 1993, 57, 365-374. [CrossRef]

55. Saunders, J.A.; Hofstra, A.H.; Goldfarb, R.J.; Reed, M.H. Geochemistry of hydrothermal gold deposits. In Treatise on Geochemistry, 2nd ed.; Elsevier: Amsterdam, The Netherlands, 2014; pp. 383-424. [CrossRef]

56. Juhani, O.V.; Iljina, M. (Eds.) Metallogeny and Tectonic Evolution of the Northern Fennoscandian Shield; Guidebook 33 IGC excursion No. 15, 15-21 August 2008; 33 IGC: Oslo, Norway, 2008; 113p.

57. Pokalov, V.T.; Semenova, N.V. The first big molybdenum deposit of the Precambrian age. Geol. Ore Dep. 1993, 35, 262-270.

58. Kuleshevich, L.V.; Tytyk, V.M.; Korotaeva, N.N. Mineralogy of ore and near-ore altered rocks in the gold-polymetsl deposit Lobash-1. Zapiski RMO 2004, 4, 39-51.

59. Kuleshevich, L.V.; Dmitrieva, A.V. Geochemical characteristics and gold mineralization of the Late Archean Taloveis diorite granite porphyry complex, Kostomuksha structure, Karelia. Proc. Karelian Sci. Cent. RAS 2014, 1, 63-75. (In Russian)

60. Ivashchenko, V.I.; Lavrov, O.B. Complex porphyry deposit Jalonvaara in the Archean of Karelia (Russia). Geol. Ore Dep. 1996, $5,412-423$.

61. Samsonov, A.V.; Larionova, Y.O.; Nosova, A.A.; Ruch'ev, A.M. The Problem of Age Position and Genesis of Gold Mineralization in the Archean Greenstone Belts of the Karelian Block: An Experience of Complex Reconstructions. (In Russian). Available online: http: / / www.minsoc.ru/viewreports.php?cid=338\&rid=1395 (accessed on 25 November 2020). 
62. Ivashchenko, V.I.; Golubev, A.I. Gold and Platinum in Karelia: Formational-Genetic Types of Mineralization and Prospects; Karelian Science Center: Petrozavodsk, Russia, 2011; 369p. (In Russian)

63. Kudryashov, N.M.; Kalinin, A.A.; Lyalina, L.M.; Serov, P.A.; Elizarov, D.V. Geochronological and isotope geochemical characteristics of rocks, hosting gold occurrences in the Archean greenstone belt Kolmozero-Voron'ya (Kola region). Lithosphere 2015, 6, 83-100. (In Russian)

64. Kalinin, A.A.; Bakaev, G.F. Gold occurrence Nyal'm-1 in the Kolmozero-Voron'ya belt: Geological and mineralogical-geochemical characteristics. In Science and Education in the Arctic Region, Proceedings of the International Scientific-Practical Conference, Murmansk, Russia, 3-7 April 2017; MSTU: Murmansk, Russia, 2017; pp. 70-76. (In Russian)

65. Eilu, P.; Pankka, H. Fingold—A Public Database on Gold Deposits in Finland; Geological Survey of Finland: Espoo, Finland, 2013. Available online: http:/ / en.gtk.fi/informationservices/palvelukuvaukset/fingold.html (accessed on 21 March 2016).

66. Maier, W.D.; Lahtinen, R.; O’Brien, H. (Eds.) Mineral Deposits of Finland; Elsevier: Amsterdam, The Netherlands, 2015; 792p, ISBN 978-0-12-410438-9. 